\title{
U-Th isotope constraints on gas hydrate and pockmark dynamics at the Niger delta margin
}

\author{
Bayon Germain ${ }^{1,{ }^{*}}$, Henderson Gideon M. ${ }^{2}$, Etoubleau Joel ${ }^{1}$, Caprais Jean-Claude ${ }^{3}$, Ruffine Livio ${ }^{1}$, \\ Marsset Tania ${ }^{1}$, Dennielou Bernard ${ }^{1}$, Cauquil Eric ${ }^{4}$, Voisset Michel ${ }^{1}$, Sultan Nabil ${ }^{1}$
}

${ }^{1}$ IFREMER, Unite Rech Geosci Marines, F-29280 Plouzane, France.

2 Univ Oxford, Dept Earth Sci, Oxford OX1 3PR, England.

${ }^{3}$ IFREMER, Unite Rech Etud Ecosyst Profonds, F-29280 Plouzane, France.

${ }^{4}$ TOTAL, F-92069 Paris, France.

*Corresponding author, Germain Bayon, email address : gbayon@ifremer.fr

\begin{abstract}
:
The application of uranium-thorium dating methods to authigenic carbonates provides unique constraints on the temporal evolution of methane seeps at ocean margins. In this study, we report U-Th isotope measurements for carbonate breccias collected from within a hydrate-bearing pockmark located at the Niger Delta margin. These concretions were extracted from a carbonate-rich layer in the upper two meters of a sediment core (N2-KS-44; $1200 \mathrm{~m}$ water depth), well above the present-day sulphatemethane transition zone (about $3 \mathrm{~m}$ depth) and the presence of gas hydrates in the sediment. The stratigraphy of core N2-KS-44 was established by tuning its downcore Al/Ti profile to a well-dated nearby reference core, and carbonate $230 \mathrm{Th} / \mathrm{U}$ ages were calculated using isochron methods.

Our results indicate that a major event of aragonite precipitation occurred between about 13 and $2.5 \mathrm{ka}$ at the studied location. Comparison of sediment accumulation rates at both core N2-KS-44 and the nearby reference site suggests that the initial stage of carbonate precipitation, between 13 and $10 \mathrm{ka}$, was associated with sediment winnowing, probably related to intense fluid seepage. In contrast, our data indicate that sedimentation rates rapidly increased within the pockmark after $7 \mathrm{ka}$. In agreement with the presence of carbonate breccias exhibiting U-Th ages older than their corresponding stratigraphic age, this observation would suggest that sediment reworking took place after that time, possibly caused by erosion of the surrounding sediment within the pockmark. We hypothesize that the period of carbonate formation between 13 and $2.5 \mathrm{ka}$ was related to an upward migration of gas-hydrate reservoirs to the near seafloor environment. After this pulse of enhanced fluid flow, the diminution of methane fluxes at the base of the local gas-hydrate occurrence zone would have led to hydrate dissolution in sub-surface sediments and pockmark formation, thereby explaining the progressive increase in sedimentation rates, the absence of recent carbonate concretions and the deepening of the sulphate-methane transition zone at site N2-KS-44 inferred from pore water data. Overall, these results provide further constraints about the relationship between gas hydrate dynamics and the evolution of pockmarks at ocean margins through time.
\end{abstract}




\section{Highlights}

- Breccias from hydrate-bearing sediments can be successfully dated with U-series. Deep carbonates precipitated between 13.0 and $2.5 \mathrm{kyr}$ at the studied pockmark. Evidence for hydrate dissolution and SMTZ fluctuations during the Holocene. Co-evolution of gas hydrate and pockmark dynamics through time.

Keywords : Gas hydrates, Pockmarks, U-series, Authigenic carbonates, Niger delta 


\section{Introduction}

Huge amounts of methane $\left(\mathrm{CH}_{4}\right)$ are stored as gas hydrates at ocean margins (Milkov, 2004; Wallmann et al., 2012), representing potentially an important component of the global carbon and methane cycles (Judd et al., 2002; Dickens, 2003). Gas hydrates are unstable phases in marine sediments, which may decompose in response to small changes in gas-saturation of the surrounding pore water, or to changes in the pressure and temperature conditions of the marine environment, such as those induced by sea-level changes, continental-slope failures, and the reorganisation of deep-ocean circulation or fluid pathway systems within the sediment column (Buffett, 2000). While isotopic records of atmospheric $\mathrm{CH}_{4}$ in ice cores indicate negligible contribution from marine gas hydrate reservoirs during the Late Quaternary (Sowers, 2006), dissociation of gas

44 hydrates stored at margins could have led episodically to substantial methane releases in 45 the past, possibly affecting both the marine environment and the atmosphere (e.g. Nisbett, 46 1990; Haq, 1998; Kennett et al., 2000; Hesselbo et al., 2000; Bangs et al., 2010). At ocean margins, the occurrence of gas hydrates in near-seafloor sediments is often associated with the presence of pockmarks, which correspond to seabed depressions related to seepage of methane-rich fluids (Hovland and Judd, 1988; Suess, 2014). Over the past decades, there has been increasing evidence for widespread distribution of both active and inactive pockmarks at margins, which questions their relationship to past fluid

52 seepage and potential episodes of gas hydrate dissociation (e.g. Hovland et al., 2002;

53 Loncke et al., 2004; Davy et al., 2010; Sultan et al., 2010; Pau et al., 2014). While 54 pockmarks are being increasingly studied, however, there are still significant 55 uncertainties on the factors controlling their activity and their evolution through time. In 56 particular, knowledge on both the timing and duration of pockmark activity is important 57 for constraining the possible links between climate change and methane seeps in the past.

Evidence for past methane releases and gas hydrate destabilisation in marine sediments has come primarily from carbon isotope signals in geological records (e.g.

61 Dickens et al., 1995; Kennett et al., 2000; Hesselbo et al., 2000; Hill et al., 2004; Panieri 62 et al., 2014). Because methane stored in sedimentary gas hydrates exhibits highly 
63 negative carbon isotope signatures, large negative $\delta^{13} \mathrm{C}$ excursions recorded by 64 foraminifera in marine sediments have been interpreted as indicators for past circulation 65 of methane-rich fluids potentially related to the dissociation of methane hydrates (e.g. 66 Kennett et al., 2000; Smith et al., 2001; Panieri et al., 2014). Authigenic carbonates 67 represent another potential archive of past fluid flow and gas-hydrate dissociation on 68 continental margins (Bohrmann et al., 1998; Naehr et al., 2000; Greinert et al., 2001). 69 The occurrence of authigenic carbonate deposits (e.g. chemoherm carbonates, carbonate 70 crusts and nodules) has been reported at many seeps worldwide (Suess, 2014). Cold seep 71 carbonates result primarily from the microbial anaerobic oxidation of methane (AOM) in 72 sediments (Boetius et al., 2000), which typically leads to enhanced alkalinity levels in 73 surrounding pore waters and, as a consequence, to carbonate precipitation. In gas74 hydrate-bearing sediments, authigenic carbonates often occur as millimeter- to 75 centimeter-size nodules of carbonate-cemented mudclast breccias or nodules (Bohrmann 76 et al., 1998; Naehr et al., 2000; Greinert et al., 2001; Bayon et al., 2007). It has been 77 suggested that such carbonates represent suitable paleo-indicators for the presence of gas 78 hydrates in marine sediments (Naehr et al., 2000; Pierre et al., 2000; Bayon et al., 2007).

Absolute dating of authigenic carbonate breccias or nodules recovered at various 81 depths within hydrate-bearing sediments can thus provide unique constraints on past 82 methane fluxes, and the evolution of gas-hydrate reservoirs in marine sediments through 83 time. Conventional ${ }^{14} \mathrm{C}$ dating is usually not applicable to authigenic carbonates because 84 their carbon partly derives from old fossil sources (i.e. methane), but several studies have 85 now demonstrated that uranium-thorium dating techniques could be successfully applied 86 to seep carbonates (Lalou et al., 1992; Teichert et al., 2003; Kutterolf et al., 2008; 87 Watanabe et al., 2008; Bayon et al., 2009a,b; Liebetrau et al., 2010; Feng et al., 2010; 88 Wirsig et al., 2012; Bayon et al., 2013; Crémière et al., 2013; Tong et al., 2013; Liebetrau 89 et al., 2014; Han et al., 2014; Berndt et al., 2014). Most of these studies have focused on 90 seafloor carbonate crusts, chimneys or chemoherms (Lalou et al., 1992; Teichert et al., 91 2003; Bayon et al., 2009a,b; Liebetrau et al., 2010; Feng et al., 2010; Wirsig et al., 2012; 92 Bayon et al., 2013; Crémière et al., 2013; Tong et al., 2013; Han et al., 2014), and drilled 93 carbonate mounds (Kutterolf et al., 2008; Liebetrau et al., 2014). To date, only a few 
94 investigations have been dedicated to the analysis of buried carbonate nodules at methane 95 seeps (Watanabe et al., 2008; Crémière et al., 2013). Although such approach may offer

96 the opportunity to investigate gas-hydrate dynamics in marine sediments during the Late 97 Quaternary, it can be complicated by diagenetic issues such as dissolution (Luff et al., 98 2005) and the presence of significant initial ${ }^{230} \mathrm{Th}$ derived from terrigenous material 99 (Watanabe et al., 2008; Bayon et al., 2009; Wirsig et al., 2012), which hence require the 100 use of isochron dating methods.

101

In this study, we report U-Th analyses for cm-size nodules of carbonate breccias 103 recovered at various depths from a hydrate-bearing sediment core at the Niger Delta 104 margin. We show below that, when combined with a well-constrained core stratigraphy, 105 this approach can provide unique information on the evolution of gas-hydrate reservoirs 106 and pockmark dynamics through time.

\section{Material and methods}

\subsection{Regional setting and sampling sites}

112 The Niger Delta is a large sedimentary edifice on the West African margin, which 113 extends southward into the Gulf of Guinea deep basin. In its deep province, gravity 114 tectonism has deformed sediments significantly, leading to folding, diapirism and

115 faulting, all of which have resulted in the migration of gas-rich fluids within continental 116 slope sediments. Numerous occurrences of fluid escape sedimentary structures and gas 117 hydrate deposits have been reported previously on the Niger Delta deep province (Brooks 118 et al., 1994; Bayon et al., 2007; Sultan et al., 2007; Sultan et al., 2010; Bayon et al., 2011; 119 Ruffine et al., 2013; Sultan et al., 2014).

The pore water, carbonate and sediment samples used for this study were collected by sediment coring during two expeditions on the continental slope off Nigeria in 2003 and

1232004 (NERIS 1 \& 2; chief scientist: M. Voisset). All samples were recovered from a 124 pockmark-rich area of $\sim 20 \mathrm{~km}^{2}$, at about $1200 \mathrm{~m}$ water depth (Fig. 1). The geological 
125 setting, occurrence of gas hydrates and geochemical processes related to carbonate 126 precipitation in the study area have been described previously (Bayon et al., 2007; Sultan

127 et al., 2007; Sultan et al., 2010; Rongemaille et al., 2011). This area corresponds to the 128 collapsed summit of an anticline, which is delimited by two deep-rooted normal faults 129 oriented N130. Between those two major faults, the central domain is characterised by 130 the presence of numerous pockmarks of variable shape and diameter (from $\sim 10 \mathrm{~m}$ to 400 $131 \mathrm{~m}$; see Fig. 1). As discussed in Bayon et al. (2007), apart from the recovery of a few 132 seafloor chemoherm deposits along the major faults, the carbonate samples collected in 133 this central domain correspond almost exclusively to carbonate breccias similar to other 134 gas hydrate-associated carbonates described elsewhere (e.g. Greinert et al., 2001). 135 Geophysical data, sediment coring and geotechnical measurements acquired during the 136 NERIS project revealed that both free gas and gas hydrates occur abundantly in this 137 central domain, in the near-seafloor environment (Sultan et al., 2007). The studied area is 138 located well within the stability field of gas hydrates in the marine environment (Fig. S1).

139 Piston core N2-KS-44 (length $6.6 \mathrm{~m} ; 1174 \mathrm{~m}$ water depth) was retrieved from one 15-m 140 deep hydrate-bearing pockmark in this area (Fig. 1). Core lithology is presented in Fig. 2. 141 No evidence for the presence of turbidites or any other mass-transport deposits was 142 encountered in core N2-KS-44. Abundant carbonate concretions were observed between 14330 and $180 \mathrm{~cm}$ sediment depth, while gas-hydrate nodules occurred deeper in the 144 sediment, below $\sim 400 \mathrm{~cm}$ (Fig. 2). Hydrate-bearing sediments from a few other cores in 145 the central domain (N1-KSF-23 and N1-KSF-20) and a nearby reference core not 146 affected by any fluid seepage (N1-KSF-39; lat. $3^{\circ} 12.208^{\prime} \mathrm{N}$; long. $6^{\circ} 41.003^{\prime} \mathrm{E}$; length $14710.60 \mathrm{~m} ; 1243 \mathrm{~m}$ water depth) were also analysed during this study (Fig. 1).

\subsection{Core stratigraphy}

150 In this study, conventional oxygen isotope stratigraphy and AMS radiocarbon dating 151 were not applicable to core N2-KS-44, due to the presence of methane-derived carbonate 152 phases dispersed along the entire core (Bayon et al., 2007). Sedimentary sequences 153 accumulated on the Niger Delta deep province display however large fluctuations in 154 major element composition, which can be used for the purpose of stratigraphic 155 correlation. In particular, the aluminium/titanium (Al/Ti) ratio represents a proxy for past 
156 chemical weathering, related to the alternance of wet and dry periods in the Niger River 157 basin during the Late Quaternary (Zabel et al., 2001). Both Al and Ti are mainly hosted 158 by silicate detrital phases; hence $\mathrm{Al} / \mathrm{Ti}$ ratios are unlikely to be affected by methane 159 seepage at cold seeps. The age model for core N2-KS-44 was therefore established by 160 tuning its downcore Al/Ti profile to the nearby reference core N1-KSF-39 (Fig. 3). Bulk 161 major element composition of N2-KS-44 and N1-KSF-39 sediments was determined by 162 wavelength-dispersive X-ray fluorescence (WD-XRF) analysis of fusion beads. The 163 chronology for core N1-KSF-39 relies on nine ${ }^{14} \mathrm{C}$-AMS radiocarbon analyses of mixed 164 planktonic foraminifera fractions (Table 1), and tuning of its $\mathrm{Al} / \mathrm{Ti}$ profile to the $\mathrm{Al} / \mathrm{Ti}$ 165 curve of core GeoB4901-8 (Fig. 3); a well-dated sediment record also recovered in the 166 Niger Delta deep province (Zabel et al., 2001). These radiocarbon dates were converted 167 into calendar ages using the Calib 7.1 program (Stuiver et al., 2013), and applying a 168 marine reservoir age of $400 \mathrm{yr}$. While this approach suffers from inherent uncertainty 169 associated with tuning methods, and especially here with the fact that the Al/Ti profile for 170 core N2-KS-44 is not particularly smooth, the relatively good correlation observed 171 between $\mathrm{Al} / \mathrm{Ti}$ signals of all three sedimentary records suggest that it can provide, to a 172 first approximation, a reliably good estimate for core N2-KS-44 stratigraphy (Fig. 3). 173 Based on these chronologies, down-core variations in sedimentation rates were calculated 174 for both core N1-KSF-39 (Table 1) and N2-KS-44 (Fig. 3).

\subsection{Pore-water analyses}

177 On board, pore waters were extracted from core N2-KS-44 sediments by 178 centrifugation, immediately after sampling, filtered using acetate cellulose filters $(0.45$ $179 \mu \mathrm{m}$ diameter) and stored in a refrigerator. Dissolved sulphate $\left(\mathrm{SO}_{4}{ }^{2-}\right)$ and chloride $\left(\mathrm{Cl}^{-}\right)$ 180 concentrations were measured onshore in 1:10 diluted solutions by ion chromatography. 181 Calcium contents were also determined with an Element2 HR-ICP-MS after simple 182 dilution (between 500 and 1000-fold) with 2\% twice sub-boiled nitric acid. Ca 183 concentrations were calculated by external calibration using diluted IAPSO and NASS-5 184 solutions. 
187 Details on the petrography and mineralogy of authigenic carbonate samples recovered 188 at site N2-KS-44 are given in Bayon et al. (2007). Polished sections of selected samples 189 were also examined by scanning electron microscopy (JEOL JSM-840A) and electron 190 microprobe analyzer (JEOL JXA8800R) to provide elemental mapping of carbonate 191 concretions and select sampling areas suitable for U-Th measurements. Authigenic 192 carbonates recovered in the upper two meters of core N2-KS-44 sediments correspond 193 typically to mm- to cm-size carbonate-cemented breccias (Bayon et al., 2007), similar to 194 those reported previously in other hydrate-bearing sediments (Naehr et al., 2000; Greinert 195 et al., 2001). Those carbonate concretions contain intraclasts (biogenic components, 196 mudstones) cemented by aragonite and/or high-Mg calcite (Fig. 4). Some concretions 197 exhibit large (up to $\sim 100 \mu \mathrm{m}$ diameter) crystals of fibrous aragonite, which have 198 developed in open pore spaces, either between intraclasts or inside the cavities of 199 biogenic components (Fig. 4). Botryoidal aragonite often composes carbonate cements.

200 Numerous intraclasts consist of mudstones cemented by microcrystalline high-Mg 201 calcite, which exhibit a darker color than the surrounding matrix and contain framboidal 202 pyrite. One concretion was recovered in a deeper core section (at $260 \mathrm{~cm} \mathrm{depth}$ ), which 203 corresponds to a homogeneous mudstone cemented by microcrystalline high-Mg calcite 204 (Fig. 2).

\subsection{Chemical and analytical procedures for U-Th measurements}

207 Selected areas of carbonate concretions from core N2-KS-44 were hand-drilled 208 carefully to obtain samples having weight ranging between 50-100 $\mathrm{mg}$ of carbonate 209 powder. However, carbonate breccias are highly heterogeneous and samples of this size 210 (referred to as 'bulk' samples in the following text) are still significantly contaminated by 211 detrital material, with consequences on U-Th dating. Therefore, to try to reduce such 212 contamination, some carbonate samples were also collected using a computer-assisted 213 microsampling device (MicroMill, New Wave Research). This system enables accurate 214 sampling of micrometer-size areas of polished sections. For those small carbonate 215 samples (referred to as 'micromilled' samples subsequently), sampling areas were 216 selected using scanning electron microscopy and/or electron microprobe analyser (Fig. 217 4). Sampling areas were chosen within both aragonite- and high-Mg calcite-rich areas of 
218 carbonate breccias. About $\sim 1 \mathrm{mg}$ of carbonate powders was collected for each of those

219 micromilled samples for U-Th analysis. A total of six bulk sediment samples containing

220 no visible carbonates were also analysed to characterize the detrital component

221 incorporated within the carbonate concretions.

223 The chemical and analytical procedures used in this study largely followed those 224 described in Bayon et al. (2009a). Briefly, each sample (i.e. bulk, micromilled, sediment) 225 was dissolved in $7.5 \mathrm{M} \mathrm{HNO}_{3}$, spiked with a mixed ${ }^{236} \mathrm{U} /{ }^{229} \mathrm{Th}$ spike, digested in 226 concentrated $\mathrm{HNO}_{3}$ on the hotplate, and centrifuged. At this stage, any undissolved 227 detrital fractions were transferred into cleaned Teflon vessels and fully digested with a 228 mixed (3:1) HF:HCl solution, before being added back into corresponding supernatants. 229 Samples were evaporated, taken up with $7.5 \mathrm{M} \mathrm{HNO}_{3}$, and diluted with ultrapure water. 230 After Fe-oxide co-precipitation, $U$ and Th were finally separated chemically using 231 conventional anion exchange techniques. The volumes of anion-exchange resin and acids 232 used for separating U-Th were much smaller for micromilled samples than for bulk and 233 sediment samples. Typical procedural blanks were $1.2 \times 10^{-10} \mathrm{~g}{ }^{238} \mathrm{U}$ and $3.0 \times 10^{-11} \mathrm{~g}$ $234{ }^{232} \mathrm{Th}$ for bulk carbonate and sediment samples, and $1.0 \times 10^{-11} \mathrm{~g}{ }^{238} \mathrm{U}$ and $1.3 \times 10^{-12} \mathrm{~g}$ $235{ }^{232} \mathrm{Th}$ for micromilled samples. Total $\mathrm{U}$ and $\mathrm{Th}$ procedural blanks were small compared 236 to final sample concentrations. $U$ and $T h$ concentrations and isotope ratios were 237 measured with a MC-ICPMS (Nu Plasma). The external reproducibility on the ${ }^{234} \mathrm{U} /{ }^{235} \mathrm{U}$ 238 ratio was assessed by measuring repeatedly the standard CRM-145 during each session 239 using a standard-bracketing measurement protocol. Th was measured with ${ }^{229} \mathrm{Th}$ and $240{ }^{230} \mathrm{Th}$ sequentially in a single ion-counter equipped with an energy filter to improve 241 abundance sensitivity, and ${ }^{232} \mathrm{Th}$ in a Faraday collector. Precision obtained on measured $242{ }^{229} \mathrm{Th} /{ }^{230} \mathrm{Th}$ ratios was always better than $5 \%$ for bulk and sediment samples, and $50 \%$ 243 for micromilled samples. Blank correction on ${ }^{230} \mathrm{Th}$ concentrations was calculated using 244 measured ${ }^{232} \mathrm{Th} /{ }^{230} \mathrm{Th}$ ratio and ${ }^{232} \mathrm{Th}$ concentration for blank. For the small-size 245 micromilled samples, blank contributions accounted for between $0.7 \%$ (N2-KS-44_75-1) 246 to $9.3 \%$ (N2-KS-44_180-1). 


\section{Results}

\subsection{Pore-water $\mathrm{SO}_{4}^{2-}, \mathrm{Cl}$ and $\mathrm{Ca}^{2+}$ profiles}

252 For core N2-KS-44, pore water $\mathrm{SO}_{4}{ }^{2-}$ concentrations display seawater-like values from 253 the surface sediment to $60 \mathrm{~cm}$ depth, and then decrease steadily to reach near-zero values

254 from $260 \mathrm{~cm}$ depth to downcore (Fig. 2). Dissolved calcium concentrations show a 255 relatively similar downcore profile, characterized by a significant drop from $\sim 10 \mathrm{mM}$ 256 (i.e. seawater values) in the upper sediment layers to about $1 \mathrm{mM}$. In contrast, chloride 257 concentrations exhibit little variation along the upper section of core N2-KS-44 ( $560 \pm$ $25822 \mathrm{mM})$.

\subsection{Electron microprobe elemental distribution maps}

261 The chemical maps obtained by electron microprobe analyser for one representative 262 carbonate breccia from core N2-KS-44 (collected at $160 \mathrm{~cm}$ depth) are presented in Fig. 263 5. The Si distribution map can be used to infer the extent to which carbonate cements 264 may be contaminated by detrital material (e.g. clays). Aragonite exhibits typically higher 265 levels of Sr than high-Mg carbonates (Fig. 5). In Fig. 5, it is also clear that aragonite-rich 266 areas are much less contaminated by detrital material (i.e. lower Si contents) than high$267 \mathrm{Mg}$ calcite-rich mudclasts and cements. We showed earlier that contamination by 268 terrigenous material in cold-seep carbonates increased as the size of crystals in the 269 carbonate cement decreases (Bayon et al., 2007). In those carbonate-cemented breccias 270 from core N2-KS-44, large fibrous crystals of aragonite, developed in open pore spaces 271 and cavities, contain much less detrital material ( $<2 \mathrm{wt} \% \mathrm{Si}$ contents) than botryoidal 272 aragonite $(<2.5 \% \mathrm{Si})$, microcrystalline aragonite $(<5 \% \mathrm{Si})$, and microcrystalline high$273 \mathrm{Mg}$ calcite (up to $7 \% \mathrm{Si}$ ). In Fig. 5, this is demonstrated by the evidence that fibrous 274 aragonite-rich areas, such as those encountered in open cavities, contain very low levels 275 of Si. Importantly, concerning U-Th dating, this also indicates that it is best to sample 276 well-crystallised aragonite-rich areas in order to reduce contamination by detrital 277 material.

\subsection{Uranium and thorium concentrations and isotopic ratios}


U-Th data for sediments and authigenic carbonates are listed in Table 2. U 281 concentrations vary between $\sim 5-17 \mathrm{ppm}$ and $\sim 2-23 \mathrm{ppm}$ for sediments and carbonates, 282 respectively. ${ }^{230} \mathrm{Th}$ concentrations range from 5 to $62 \mathrm{ppt}$ (mean average of $33 \mathrm{ppt}$ ) in 283 authigenic carbonates and from 80 to $105 \mathrm{ppt}$ in sediments. Carbonate $\left({ }^{230} \mathrm{Th} /{ }^{232} \mathrm{Th}\right)$ 284 ratios (brackets indicate activity ratios) are low (from 1.2 to 5.3; Table 3), due to both the 285 young formation age of carbonates (low ${ }^{230} \mathrm{Th}$ ingrowth) and detrital contamination (high 286 initial ${ }^{232} \mathrm{Th}$ ). Micromilled samples for aragonite-rich concretions exhibit higher $287 \quad{ }^{238} \mathrm{U} /{ }^{232} \mathrm{Th}$ ) ratios (from 6.4 to 32.3 ; Table 2) than sediments (from 1.2 to 4.4; Table 2) 288 and corresponding bulk carbonates (from 5.2 to 20.6; Table 2). This indicates that 289 micromilling has been successful in sampling carbonate with lower detrital contents. In

290 contrast, Mg-rich carbonates generally display comparatively lower $\left({ }^{230} \mathrm{Th} /{ }^{232} \mathrm{Th}\right)$ and $291 \quad\left({ }^{238} \mathrm{U} /{ }^{232} \mathrm{Th}\right)$ ratios even in micromilled subsamples, reflecting both the fact that calcite is 292 less enriched in U compared to aragonite, and that high-Mg microcrystalline carbonate 293 phases are more enriched in detrital components (Bayon et al., 2007).

\subsection{U-Th isochron dating}

296 Isochron dating methods consider each sample to be composed of a mixture of two 297 components. In this case, they can be used to separate ${ }^{230} \mathrm{Th}$ present initially from that 298 ingrown from $\mathrm{U}$ in the carbonate. By analysing several subsamples of the same age but 299 with different proportions of the two components, it is possible to calculate the age 300 corresponding to the end-member with no initial ${ }^{230} \mathrm{Th}$ (Edwards et al., 2003). In seep301 related studies, this approach may be complicated by the fact that authigenic concretions 302 may have recorded several discrete events of carbonate precipitation. In this case, 303 isochron methods may also prove to be particularly useful for assessing whether studied 304 concretions are polygenic or instead correspond to single precipitation events. In this 305 study, we have considered a sediment end-member, assumed to be representative of the 306 initial sediment fraction incorporated by carbonate breccias. The U-Th isotopic 307 composition of this sediment fraction can be influenced by its mineralogical composition 308 and the amount of incorporated hydrogenous ${ }^{230} \mathrm{Th}$ derived from the overlying water 309 column. Using a typical sediment end-member to correct ages is more appropriate than 310 correcting each sample with a sediment measurement from the same core. The latter 
311 approach would generate isochrons containing two high-precision data points, leading to 312 unrealistically precise calculated ages which do not incorporate any uncertainty due to 313 possible variability in the sediment. The approach of defining a typical sediment end314 member for one given area circumvents this problem and leads to larger but more 315 realistic age uncertainties, thereby allowing calculation of less precise but more accurate 316 ages. Another possible approach would have been to consider a sediment end-member 317 assumed to be at secular equilibrium, i.e. with activity ratios of $1.0 \pm 0.5$ (e.g. Bayon et 318 al., 2013). While it may seem more appropriate to apply a regional sediment end319 member for correction, note that the use of a theoretical end-member would have led to 320 the same conclusions, yielding very similar isochron ages (always within $25 \%$ ). In this 321 study, the sediment end-member has been defined as the average ( $\pm 1 \mathrm{SD}$ ) of six 322 sediments from our study area (Table 3). All these sediments were recovered from 323 seepage sites and hence can be considered, to a first approximation, as representative of 324 the sediment incorporated by the studied carbonate concretions, even in the eventuality 325 that circulation of methane-rich fluids may alter the U-Th isotopic composition of the 326 sediment. On a $\left({ }^{230} \mathrm{Th} /{ }^{232} \mathrm{Th}\right)$ versus $\left({ }^{238} \mathrm{U} /{ }^{232} \mathrm{Th}\right)$ plot (Fig. S2), these sediments are 327 clustered near the equiline, with typical crustal values $(\sim 1.0)$. This indicates a 328 reasonably homogeneous source of initial Th for carbonate breccias in the studied area, 329 and suggests that isochron dating using this sediment end-member is suitable.

331 Isochron diagrams and ages obtained with the sediment end-member are presented in Fig.

3326 and Table 3. Isochron ages were calculated with Isoplot-Ex 3.70 (Ludwig, 2008), using 333 measured $\left({ }^{232} \mathrm{Th} /{ }^{238} \mathrm{U}\right),\left({ }^{230} \mathrm{Th} /{ }^{238} \mathrm{U}\right)$ and $\left({ }^{234} \mathrm{U} /{ }^{238} \mathrm{U}\right)$ ratios (Table 3$)$. The ${ }^{230} \mathrm{Th} / \mathrm{U}$ age 334 errors were calculated by a Monte Carlo simulation, rather than from the first-derivative 335 expansion which led, in the case of this study, to unrealistically small errors. However, 336 when the use of Monte Carlo solution was not possible, an arbitrary error of $\pm 25 \%$ was 337 assigned to the obtained isochron ages. This arbitrary error corresponds to the external 338 reproducibility on isochron ages estimated from repeated analyses of an in-house cold 339 seep carbonate standard (Bayon et al., 2013). 
341 In Table 3, two isochron ages are reported: 1) two-point $(n=2)$ isochron ages, which 342 provide an age estimate for every analysed sample; and 2) pseudo-isochron ages (with $343 \mathrm{n}>2$ ) that integrate, for any given concretion, all the studied sub-samples. As can be seen

344 in Fig. 6 (Osmond isochron diagrams), except for the concretion at $75 \mathrm{~cm}$ depth, the 345 distinct fractions (e.g. bulk concretion, micromilled carbonate phases, associated 346 sediment, average composition of the local sediment) associated with carbonate breccias 347 are remarkably well aligned along pseudo-isochron slopes, suggesting that they formed

348 cogenetically. Importantly, this observation also provides strong support for the validity 349 of calculated pseudo-isochron ages and indicates adequate correction of contamination 350 from inherited Th. In contrast, the studied subsamples from the concretion at $75 \mathrm{~cm}$ 351 depth are not aligned in Fig. 6, suggesting that they probably did not form 352 contemporaneously (see discussion below). In this case, only the two-point isochron ages 353 will hence be considered in the following discussion.

355 Within error (2s), most carbonate breccias display isochron corrected $\delta^{234} U_{(T)}$ values 356 similar to seawater values $\left(\delta^{234} U=146.6 \pm 2.5 \%\right.$ (Robinson et al., 2004; Table 3), 357 suggesting that they formed in the near-seafloor environment. The calculated isochron 358 ages range from $4.8 \pm 1.4$ to $15.6 \pm 1.6$ thousand years before present (ka; or ka). All 359 analysed samples (bulk, micromilled, associated sediment) for the upper carbonate-rich 360 layer at $30 \mathrm{~cm}$ depth yield a pseudo-isochron age of $8.5 \pm 0.2 \mathrm{ka}(\mathrm{n}=4$; i.e. four-point 361 isochron). Isochron ages of $9.4 \pm 2.4(\mathrm{n}=5)$ and $10.8 \pm 2.7 \mathrm{ka}(\mathrm{n}=3)$ were also obtained

362 for carbonate breccias collected at $160 \mathrm{~cm}$ and $180 \mathrm{~cm}$, respectively. The three carbonate 363 samples (bulk, micromilled-1, micromilled-2) analysed for the sediment layer at $75 \mathrm{~cm}$ 364 depth define two-point isochron ages of $9.3 \pm 2.0 \mathrm{ka}, 12.4 \pm 1.3 \mathrm{ka}$ and $4.8 \pm 1.4 \mathrm{ka}$, 365 respectively. Finally, the two bulk samples from the homogeneous nodule of high-Mg 366 calcite at $260 \mathrm{~cm}$ gives a pseudo isochron age of $15.6 \pm 1.6 \mathrm{ka}(\mathrm{n}=3)$. 
372 In cold seep environments, AOM occurs typically within a localized horizon in marine 373 sediments, called the sulphate-methane transition zone (SMTZ), where both $\mathrm{SO}_{4}{ }^{2-}$ and

$374 \mathrm{CH}_{4}$ are consumed by microbial assemblages (Reeburg, 1976; Boetius et al., 2000).

375 Other biogeochemical processes, such as the degradation of organic matter (Froelich et 376 al., 1979), or the consumption of $\mathrm{C}_{2+}$ hydrocarbon compounds (Joye et al., 2004), may 377 also consume $\mathrm{SO}_{4}{ }^{2-}$ from pore waters in marine sediments. However, at cold seeps, 378 AOM is generally the main process controlling sulphate depletion, leading to near379 complete $\mathrm{SO}_{4}{ }^{2-}$ depletion at the SMTZ depth (Niewöhner et al., 1998; Borowski et al., 380 1999) and producing pseudo-linear $\mathrm{SO}_{4}{ }^{2-}$ profiles in pore-waters, similar to what can be 381 observed at site N2-KS-44 (Fig. 2). In hydrate-bearing settings, the SMTZ depth is also 382 often correlated with the occurrence of gas hydrate within the sediment (e.g. Borowski et 383 al., 1999). In the study area, this feature is nicely illustrated when plotting the SMTZ 384 depth versus the depth of occurrence of gas hydrate layers within distinct sediment cores, 385 which both define a very good correlation (Fig. 7). Gas hydrates generally hamper the 386 ascent of fluids and reduce their transport towards the seafloor (e.g. Sultan et al., 2010; Li 387 et al., 2014; Crutchley et al., 2015). However, without gas supply to sustain their 388 formation, hydrates dissolve away to stay in thermodynamic equilibrium with 389 surrounding pore waters (e.g. Ecker et al., 1998). This dissolution process contributes to 390 permanent supply of methane to pore waters above gas hydrate layers, acting as a driving 391 force for the AOM reaction coupled with sulphate reduction (Sultan et al., 2010, 2014).

392 Note that the 'dissolution' process that we refer to here differs from 'dissociation', which 393 generally occurs whenever gas hydrates leave their temperature-pressure stability field, in 394 response for example to a sea-level drop or a rise in bottom-water temperature.

396 At site N2-KS-44, the profile for pore-water $\mathrm{Ca}^{2+}$ concentrations also shows a strong 397 depletion at $\sim 3.6 \mathrm{~m}$ depth (Fig. 2), which indicates that active carbonate precipitation is 398 currently taking place at the depth of present-day SMTZ. This is in full agreement with 399 evidence for the presence of dispersed high-Mg calcite phases at this depth in core N2$400 \mathrm{KS}-44$, inferred from modelling of bulk sediment $\mathrm{Sr} / \mathrm{Ca}$ and $\mathrm{Mg} / \mathrm{Ca}$ ratios (Bayon et al., 401 2007). Overall, our pore water data indicate that the present-day AOM and associated 402 authigenic carbonate precipitation occurs at depth close to $3 \mathrm{~m}$ in core N2-KS-44, hence 
much deeper than the overlying carbonate-rich layer of authigenic concretions

404 encountered between $\sim 30$ and $180 \mathrm{~cm}$ depth.

\subsection{A major event of carbonate precipitation between $\sim 13.0$ and $2.5 \mathrm{ka}$}

407 The comparison of U-Th isochron ages for carbonate-cemented breccias with their 408 corresponding stratigraphic age (inferred from $\mathrm{Al} / \mathrm{Ti}$ tuning) can provide temporal 409 constraints on the formation of the carbonate-rich layer located in the upper two meters of 410 core N2-KS-44. Stratigraphically, this horizon corresponds to the approximate time 411 interval 2.5-13.0 ka, which hence overlaps relatively well the observed range of 412 calculated U-Th ages for carbonate breccias from $4.8 \pm 1.4$ to $12.4 \pm 1.3 \mathrm{ka}$ (Fig. 8). This

413 observation suggests that the carbonate-breccias were formed in close proximity to the 414 seafloor. This hypothesis is supported by the evidence that the carbonate breccias 415 collected at $75 \mathrm{~cm}$ (for the micromilled-2 subsample), $160 \mathrm{~cm}$ and $180 \mathrm{~cm}$ depth provide 416 U-Th isochron ages similar (within error) to their corresponding stratigraphic age (Fig. 417 8). Another argument in favor of a near-seafloor precipitation is the presence of 418 aragonite, which is generally favored over that of calcite at high $\mathrm{SO}_{4}{ }^{2-}$ concentrations or 419 when uprising fluids have a high velocity flow, hence whenever AOM proceeds in the 420 near-seafloor environment (e.g. Burton, 1993; Aloisi et al., 2000; Luff and Wallman, 421 2003; Bayon et al., 2009a).

In contrast, the two carbonate breccias from the upper carbonate-rich layer, i.e. those 424 collected at $30 \mathrm{~cm}$ and $75 \mathrm{~cm}$ depth (with the exception of the micromilled-2 subsample), 425 display isochron ages older than their respective stratigraphic age (Fig. 8), indicating 426 possible sediment reworking. An interesting feature of our results is also the evidence for 427 the presence of polygenic breccias. The two micromilled samples from the concretion 428 collected at $75 \mathrm{~cm}$ depth display distinct $\mathrm{U}$-Th isochron ages $(12.4 \pm 1.3 \mathrm{ka}$ and $4.8 \pm 1.4$ 429 ka), which suggests that such breccias may have recorded several precipitation events. In 430 this context, the bulk sample $(9.3 \pm 2.0 \mathrm{ka})$ analysed for that particular carbonate breccia 431 most likely corresponds to a mixture between distinct polygenic carbonate phases. For 432 this particular concretion, the fact that the high-Mg rich micromilled sample appears to be 433 younger than the aragonite one could possibly indicate that high-Mg carbonate phases 
434 preferentially formed after an initial event of aragonite precipitation, perhaps after 435 subsequent burial of concretions within the sediment. At this stage, petrographic 436 examination does not reveal any clear succession of different carbonate precipitation 437 events that could possibly explain the observed age/mineralogical differences in the 438 studied breccias (Fig. 4). In fact, some high-Mg rich micro-concretions observed in the 439 studied carbonate breccias (see Fig. 4e) even appear to be older than corresponding 440 aragonite cement, which would go in opposite direction to what can be proposed based 441 on our U-Th dates for the two micromilled samples at $75 \mathrm{~cm}$ depth. The observed 442 complex nature of the studied carbonate breccias clearly show that a much larger U-Th 443 investigation of additional micromilled samples from the same core would be needed to 444 identify whether distinct carbonate precipitation events occurred during the last few 445 thousand years. In addition, one cannot exclude that other breccias present in this core 446 section are older or younger than those analysed in this study. Therefore, to a first 447 approximation, and despite indications for a potentially more complex formation 448 scenario, the comparison of U-Th isochron ages for carbonate-cemented breccias with 449 their corresponding stratigraphic age suggest that carbonate formation at site N2-KS-44 450 was probably active in the near-seafloor environment during a relatively well-defined 451 time interval, between about 13 and $2.5 \mathrm{ka}$.

\subsection{Constraints on pockmark dynamics}

455 significantly older than their corresponding stratigraphic age suggests that sediment 456 reworking may have taken place at site N2-KS-44. Further constraints on pockmark 457 evolution at the studied site can also be obtained by comparing carbonate U-Th ages with 458 the sediment accumulation rates inferred for cores N2-KS-44 and N1-KSF-39 (Fig. 8). 459 From $\sim 30$ to $13 \mathrm{ka}$, the two neighbour cores were characterized by similar sedimentation 460 rates, in the range $\sim 4-10 \mathrm{~cm} / \mathrm{kyr}$, thereby suggesting a similar depositional context. 461 However, after $13 \mathrm{ka}$, sedimentation rates at the two sites started to be decoupled. 462 Between about 13 and $7 \mathrm{ka}$, the reference site (N1-KSF-39) experienced rapidly 463 increasing sedimentation rates (up to $\sim 23 \mathrm{~cm} / \mathrm{kyr}$ ), probably in relation with much higher 464 fluvial discharges from the Niger River basin (Pastouret et al., 1978; Zabel et al., 2001), 
465 before returning to much lower sediment accumulation after $7 \mathrm{ka}$ (about $5 \mathrm{~cm} / \mathrm{kyr}$ ). In 466 contrast, at site N2-KS-44, sedimentation rates remained relatively low (below $8 \mathrm{~cm} / \mathrm{kyr}$ )

467 until about $10 \mathrm{ka}$, before increasing steadily to about $18 \mathrm{~cm} / \mathrm{kyr}$ for the remaining 468 Holocene period. To account for the observed decoupling, we propose that intense 469 circulation of methane-rich fluids near the seafloor led to highly dynamic seafloor 470 environment at site N2-KS-44 between $\sim 13$ to $10 \mathrm{ka}$ (Fig. 9b). This event would have 471 resulted in seafloor carbonate precipitation, but also in intense fluid seepage and 472 associated particle resuspension or sediment winnowing (Fig. 9b). Instead, from $10 \mathrm{ka}$ 473 onwards, the shift towards enhanced sedimentation rates at site N2-KS-44 could possibly 474 be related to a second evolutionary stage of the pockmark, characterized by collapse 475 depression (Fig. 9c). Recent studies have shown that pockmarks and other seafloor 476 depressions are often characterized by higher sedimentation rates compared to the 477 surrounding seafloor (e.g. Pau and Hammer, 2013; Pau et al., 2014). The same studies 478 have also shown that sedimentation patterns at pockmarks are typically associated with 479 deposition of coarse-grained material, transported as bedload. Based on the above 480 consideration, one hypothesis would be that the presence of carbonate concretions older 481 than corresponding stratigraphic ages in the upper carbonate-rich layer relates to 482 subsequent reworking of small carbonate breccias during the period that followed intense 483 fluid seepage. This would mean that some of the studied concretions in the upper 484 aragonite-rich layer of core N2-KS-44 may be derived from the erosion of the 485 surrounding seafloor, perhaps in response to the deepening of the pockmark (Fig. 9c). 486 Another argument that would support sediment reworking after $10 \mathrm{ka}$ would be the 487 'sawtooth' A1/Ti profile along core N2-KS-44, which contrasts with the much smoother 488 Al/Ti curves observed at reference sites N1-KSF-39 and GeoB4901-8 (Fig. 3).

\subsection{Evidence for fluctuating SMTZ over the last $15 \mathrm{ka}$}

491 In contrast with the breccias from the upper carbonate-rich layer, the homogeneous 492 nodule of high-Mg calcite collected at $260 \mathrm{~cm}$ depth appears to be significantly younger $493(15.6 \pm 1.6 \mathrm{ka})$ than its corresponding estimated stratigraphic age (about $24 \mathrm{ka}$; Fig. 8). 494 Considering the average sedimentation rate inferred from our Al-Ti-tuned age model for 495 that section of core N2-KS-44 ( $7.3 \mathrm{~cm} / \mathrm{kyr}$; Fig. 3), we can estimate that this nodule 
496 formed at about $60 \mathrm{~cm}$ below the seafloor. This would explain why it is mainly composed

497 of high-Mg calcite rather than aragonite, which more commonly precipitates at the

498 sediment-seawater interface.

As mentioned above (section 4.1), the depth at which AOM and associated carbonate precipitation occurs in hydrate-bearing sediments of the study area is controlled primarily by the occurrence depth of gas hydrate layers (Fig. 7). Most likely, during the Holocene, both AOM and associated carbonate precipitation took place near the seafloor at site N2-

$504 \mathrm{KS}-44$, thereby explaining the formation of the aragonite-rich layer that is currently 505 located between $30 \mathrm{~cm}$ and $180 \mathrm{~cm}$ depth. Instead, our U-Th data for the carbonate 506 nodule at $260 \mathrm{~cm}$ depth suggest that the paleo-SMTZ at about $15.6 \mathrm{ka}$ was probably located deeper in the sediment column (about $60 \mathrm{~cm}$ depth; Fig. 9a). Taken together with our pore-water analyses and inferred depth for the present-day SMTZ (i.e. about $300 \mathrm{~cm}$ depth), these data hence indicate methane fluxes must have fluctuated significantly over the last $15 \mathrm{kyr}$ at the studied site (Fig. 9).

\subsection{Factors controlling gas hydrate dynamics and associated $\mathrm{CH}_{4}$ fluxes in Niger Delta} 513 sediments

514 Field observations and measurements have shown that the distribution of gas hydrates 515 within sediments is highly heterogeneous in hydrate-bearing areas, both at small (meter) 516 and regional scales (Tréhu et al., 2004; Sultan et al., 2007). Gas hydrates are found 517 typically in meter-thick patchy zones in marine sediments (Kvenvolden and Lorenson, 518 2001; Tréhu et al., 2004). In Niger Delta sediments, such a large heterogeneity for gas

519 hydrate distribution was confirmed by geophysical surveying and coring during the 520 NERIS expeditions (Sultan et al., 2007) and subsequent cruises (Sultan et al., 2010; 521 Sultan et al., 2014; Wei et al., 2015). It is likely, therefore, that variations in upward 522 methane fluxes from one site to another are controlled primarily by the heterogeneous 523 distribution of gas hydrates within sediments, or the presence of faults acting as a major 524 methane conduit. Considering a given hydrate-bearing site (e.g. Site N2-KS-44), 525 however, it is expected that changes in the $\mathrm{CH}_{4}$ flux over time are caused by parameters 526 affecting the dynamic of gas-hydrate deposits, such as changes in e.g. hydrostatic 
527 pressure, bottom-water temperature, slope stability, and in situ $\mathrm{CH}_{4}$ flux and/or 528 concentration at the base of the gas-hydrate occurrence zone (GHOZ) within the 529 sediment. Below, we investigate whether each of those four different factors may have 530 accounted for the inferred fluctuations of the SMTZ depth (and associated methane 531 fluxes) at site N2-KS-44.

533 Sea-level rise since the last 15,000 years is unlikely to have led to gas-hydrate 534 dissociation in Niger Delta sediments. Instead, increasing hydrostatic pressure at that 535 time contributed most probably to an opposite effect, i.e. greater gas hydrate stability in 536 sediments. Alternatively, reorganization of intermediate-water circulation during the 537 Holocene period could have induced an increase in bottom-water temperatures, leading to 538 partial dissociation of hydrate layers in sediments (see Fig. S1). This would need to be 539 tested in future studies, but at present, to the best of our knowledge, there is no evidence 540 for deep-sea temperature changes over glacial-interglacial timescales in the Tropical 541 Atlantic for the water depth considered in this study. Sedimentation rates were 542 apparently higher on the Niger deep-sea fan between 13 to $10 \mathrm{ka}$, as shown by our own 543 data (Table 1) and in agreement with previous studies (Pastouret et al., 1978; Zabel et al., 544 2001). This was due probably to high fluvial discharges at the onset of the so-called 545 Holocene thermal maximum ( 11-6 ka) in subtropical Africa, i.e. a progressive climatic 546 shift towards warmer and wetter conditions related to maximum summer insolation. This 547 could have possibly triggered slope failures and, in turn, to destabilization of gas hydrate 548 reservoirs within sediments. However, in absence of any evidence for sediment 549 instabilities in the studied area, higher sedimentation rates at that time led most likely to 550 even greater hydrate stability instead.

552 Based on the above, we argue that the inferred variation of methane fluxes at site N2553 KS-44 has not been driven by external parameters during the last 15,000 years, but 554 instead by internal processes. Previous studies have already suggested that local fluid 555 flow dynamics was likely to explain both the evolution of gas-hydrate reservoirs and 556 associated pockmarks (Cathles et al., 2010; Sultan et al., 2010; Sultan et al., 2014). In 557 this area, the occurrence of gas hydrate reservoirs in sub-surface sediments is related to 
558 high fluid pressure in the deeper sedimentary column, and associated migration of both

559 free gas and methane-rich fluids along fractures (Sultan et al., 2014). Periodically, as a

560 consequence of enhanced fluid flow, gas hydrate fronts can move both upwards and

561 laterally in shallower sediments. Therefore, at site N2-KS-44, the period of intense fluid

562 activity after $13 \mathrm{ka}$ inferred from our data hence probably corresponds to a particular

563 episode of high free gas and fluid pressure at the base of the GHOZ, which led to gas-

564 hydrate formation near the seafloor.

\subsection{Implications on the evolution of hydrate-bearing pockmarks through time}

567 The timing of pockmark formation has been often discussed in previous studies, in 568 particular through the application of U-Th dating to cold seep carbonates. Carbonate U569 Th investigations conducted at various seeps worldwide (e.g. Gulf of Mexico, Japan Sea, 570 Black Sea, Congo margin, Hikurangi margin, South China Sea) have led to the 571 suggestion that pockmark formation often took place during low sea-level stands in the 572 past (Watanabe et al., 2008; Feng et al., 2010; Liebetrau et al., 2010; Tong et al., 2013;

573 Han et al., 2014). The reduced hydrostatic pressure that has accompanied previous sea574 level falls is thought to have resulted in both enhanced fluid flow and hydrate 575 dissociation, which ultimately led to pockmark formation and authigenic carbonate 576 precipitation. Other factors have been also evoked as possible mechanisms accounting 577 for past hydrate destabilisation events and/or pockmark formation, which include e.g. 578 changes in bottom water temperatures (Mienert et al., 2005; Ménot and Bard, 2010; 579 Berndt et al., 2014; Pau et al., 2014), dissolved sulfate contents (Crémière et al., 2013), 580 seismic activity (Liebetrau et al., 2010; Fischer et al., 2013). In our study, as discussed 581 above and in agreement with earlier works (Sultan et al., 2010; Sultan et al., 2014), gas 582 hydrate and pockmark dynamics have been probably mainly driven by internal factors, at 583 least over the last few thousand years. At a longer time scale, of course, one cannot 584 exclude that external parameters such as sea-level changes also played an important role 585 in controlling fluid seepage intensity in the Niger delta area, especially at seep sites 586 located at shallower water depths. 
588 In marked contrast, very little information exists about the evolution of hydrate-bearing 589 pockmarks through time. This is simply because such information can only be derived 590 from numerical modeling (e.g. Sultan et al., 2010) or analytically challenging high591 resolution U-Th investigations of authigenic carbonate deposits or buried concretions

592 along sediment cores (Watanabe et al., 2008; Crémière et al., 2013). In this regard, our 593 study provides interesting constraints about the duration and evolution of hydrate-bearing 594 pockmark at margins.

596 Our results first suggest that the presence of gas hydrate reservoirs near the seafloor can 597 sustain continuous methane seepage and associated carbonate precipitation for several 598 thousand year long periods of time. Interestingly, at site N2-KS-44, the duration of this 599 event of enhanced seepage activity and gas-hydrate growth, associated carbonate 600 precipitation, and subsequent hydrate dissolution inferred from our results (i.e. about 60110,000 years) agrees relatively well with estimates obtained by numerical modeling for 602 the same study area (about 8,000 years; Sultan et al., 2010). In this latter work, the 603 calculated duration corresponded to the period of gas hydrate dissolution that followed a 604 sudden theoretical cessation of methane supply from the underlying sediment column. 605 While gas hydrates may form rapidly, their long-term preservation in sub-surface 606 sediments is indeed ultimately controlled by the sustainability of methane inputs from 607 deeper sediments (Sultan et al., 2014). Gas-hydrate dissolution occurs whenever the 608 methane flux and/or concentration at the base of the GHOZ decreases. The upper layers 609 of gas hydrate reservoirs are generally those that start dissolving first in response to a 610 local decrease of methane fluxes (Sultan et al., 2010). Hydrate dissolution generally 611 leads to an increase of pore-water pressure and, in turn, to sediment collapse and 612 pockmark formation (Sultan et al., 2010; Sultan et al., 2014). In this context, the inferred 613 mode of gas hydrate evolution can be referred to as rapid hydrate growth versus slow 614 hydrate dissolution (Sultan et al., 2014). This latter model that links hydrate dynamics 615 and the evolution of pockmark through time agrees very well with our own observations 616 based on carbonate U-Th dating and inferred sedimentation rates (Fig. 9). Based on our 617 data alone, however, it would remain difficult to argue whether the observed pockmark 
618 evolution at site N2-KS-44 and the recent deepening the SMTZ inferred from our pore-

619 water data are related to a sudden, or instead a progressive, decrease of methane fluxes.

\section{5. Concluding remarks}

624 In this study, we have been able to reconstruct the temporal evolution of gas hydrate

625 deposits and associated methane fluxes at a pockmark on the Niger Delta margin, using 626 an original approach based on: 1) U-Th dating of methane-derived carbonate breccias 627 collected at various depths along a sediment core, 2) the determination of corresponding 628 stratigraphic ages and inferred sedimentation rates, and 3) acquisition of pore water data. 629 At the studied location, a major episode of carbonate precipitation occurred between 630 about 13.0 and $2.5 \mathrm{ka}$, probably triggered by the upward migration of gas hydrate 631 reservoirs to near the seafloor. Enhanced methane fluxes in the upper sediment layers 632 were probably first accompanied with intense fluid seepage and sediment winnowing at 633 the seafloor. After this initial phase, we propose that hydrate dissolution prevailed in 634 sub-surface sediments, probably in response to decreasing methane fluxes at the base of 635 the local gas hydrate occurrence zone. Presumably, this would have led to pockmark 636 formation and the deepening of the sulphate-methane transition zone, in agreement with 637 evidence from present-day pore-water data. This would also be supported by evidence for 638 rapidly increasing sedimentation rates at the same time and the presence of carbonate 639 concretions older than corresponding stratigraphic ages, which both suggest sediment 640 erosion and/or reworking.

642 Similarly to what has been previously proposed for the same area based on numerical 643 modeling, our results suggest that the activity of pockmarks in the Niger Delta area is 644 strongly related to gas hydrate dynamics. In future work, the methodology developed in 645 this study could provide interesting insights into the co-evolution of gas hydrate 646 reservoirs and pockmarks at margins. In particular, high-resolution U-Th studies of cold 647 seep carbonates from hydrate-bearing areas should aim at further investigating the 648 resilience of gas hydrate reservoirs and associated pockmark activity to past 
649 environmental changes, especially in the context of ongoing global warming and its 650 potential impact on submarine gas hydrate reservoirs.

651

652

\section{Acknowledgements}

654 This work has been funded by IFREMER and Total, through the NERIS project, and by a 655 Royal Society grant to G.M. Henderson. We kindly thank all the crew on-board of RV 656 Suroît and RV Atalante. Andrew Mason and Norman Charnley (Univ. Oxford) are 657 warmly thanked for help during U-Th and electron microprobe analyses. We gratefully 658 acknowledge Gert de Lange (Editor) and the anonymous reviewers who provided useful 659 and constructive comments on earlier versions of the manuscript. 


\section{REFERENCES}

Aloisi, G., Pierre, C., Rouchy, J.M., Foucher, J.P., Woodside, J., the MEDINAUT Scientific Party, 2000. Methane-related authigenic carbonates of eastern Mediterranean Sea mud volcanoes and their possible relation to gas hydrate destabilisation. Earth Planet. Sci. Lett. 184, 321-338.

Bangs, N.L., Hornbach, M.J., Moore, G.F., Park, J.-O., 2010. Massive methane release triggered by seafloor erosion offshore southwestern Japan. Geology 38, 1019-1022.

Bayon, G., Pierre, C., Etoubleau, J., Voisset, M., Cauquil, E., Marsset, T., Sultan, N., Le Drezen, E., Fouquet, Y., 2007. $\mathrm{Sr} / \mathrm{Ca}$ and $\mathrm{Mg} / \mathrm{Ca}$ ratios in Niger Delta sediments: Implications for authigenic carbonate genesis in cold seep environments. Mar. Geol. 241, 93-109.

Bayon, G., Henderson, G.M., Bohn, M., 2009a. U-Th stratigraphy of a cold seep carbonate crust. Chem. Geol. 260, 47-56.

Bayon, G., Loncke, L., Dupré, S., Caprais, J.-C., Ducassou, E., Duperron, S., Etoubleau, J., Foucher, J.-P., Fouquet, Y., Gontharet, S., Henderson, G.M., Huguen, C., Klaucke, I., Mascle, J., Migeon, S., Olu-Le Roy, K., Ondréas, H., Pierre, C., Sibuet, M., Stadnitskaia, A., Woodside, J., 2009b. Multi-disciplinary investigation of fluid seepage on an unstable margin: The case of the Central Nile deep sea fan. Mar. Geol. 261, 92-104.

Bayon, G., Birot, D., Ruffine, L., Caprais, J.C., Ponzevera, E., Bollinger, C., Donval, J.P., Charlou, J.L., Voisset, M., Grimaud, S., 2011. Evidence for intense REE scavenging at cold seeps from the Niger Delta margin. Earth Planet. Sci. Lett. 312, 443-452.

Bayon, G., Dupré S., Ponzevera, E., Etoubleau, J., Chéron, S., Pierre, C., Mascle, J., Boetius, A., de Lange G., 2013. Formation of carbonate chimneys in the Mediterranean Sea linked to deep-water oxygen depletion. Nat. Geosci. 6, 755-760.

Berndt, C., Feseker, T., Treude, T., Krastel, S., Liebetrau, V., Niemann, H., Bertics, V.J., Dumke, I., Dünnbier, K., Ferré, B., Graves, C., Gross, F., Hissmann, K., Hühnerbach, 
V., Krause, S., Lieser, K., Schauer, J., Steinle, L., 2014. Temporal Constraints on Hydrate-Controlled Methane Seepage off Svalbard. Science 343, 284-287.

Bohrmann, G., Meinert, J., Suess, E., Torres, M., 1998. Authigenic carbonates from the Cascadia subduction zone and their relation to gas hydrate stability. Geology 26, 647650.

Boetius, A., Ravenschlag, K., Schubert, C.J., Rickert, D., Widdel, F., Gieseke, A., Amann, R., Jorgensen, B.B., Witte, U., Pfannkuche, O., 2000. A marine microbial consortium apparently mediating anaerobic oxidation of methane. Nature 407, 623626.

Borowski, W.S., Paull, C.K., Ussler III, W., 1999. Global and local variations of interstitial sulphate gradients in deep-water, continental margin sediments: Sensitivity to underlying methane and gas hydrates. Mar. Geol. 159, 131-154.

Brooks, J.M., Anderson, A.L., Sassen, R., MacDonald, I.R., Kennicutt II, M.C., Guinasso Jr., N.L., 1994. Hydrate occurrences in shallow subsurface cores from continental slope sediments. In Annals of the New York Academy of Sciences 715, 381-391.

Buffett, B.A., 2000. Clathrate hydrates. Annu. Rev. Earth Planet. Sci. 28, 477-507.

Burton, E.A., 1993. Controls on marine carbonate cement mineralogy: review and reassessment. Chem. Geol. 105, 163-179.

Cathles, L.M., Su, Z., Chen D., 2010. The physics of gas chimney and pockmark formation, with implications for assessment of seafloor hazards and gas sequestration. Mar. Petrol. Geol. 27, 82-91.

Crémière, A., Bayon, G., Ponzevera, E., Pierre, C., 2013. Paleo-environmental controls on methane-derived carbonate authigenesis in the Sea of Marmara. Earth Planet. Sci. Lett. 376, 200-211.

Crutchley, G. J., Fraser, D. R. A., Pecher, I. A., Gorman, A. R., Maslen, G., Henrys, S. A., 2015. Gas migration into gas hydrate-bearing sediments on the southern Hikurangi margin of New Zealand. J. Geophys. Res. Solid Earth 120, 725-743.

Davy, B., Pecher, I.A., Wood, R., Carter, L., Gohl, K., 2010. Gas escape features off New Zealand - Evidence for a massive release of methane from hydrates. Geophys. Res. Let. 37, L21309. 
de Prunelé, A., Ruffine, L., Riboulot, V., Peters, C.A., Croguennec, C., Guyader, V., Pape, T., Bollinger, C., Bayon, G., Caprais, J.C., Donval, J.P., Marsset, T., Bohrmann, G., Géli, L., Rabiu, A., Lescanne, M., Cauquil, E., Sultan, N., 2015. Focused hydrocarbon-migration in shallow sediments of a pockmark cluster in the Niger Delta. Mar. Petrol. Geol. (submitted).

Dickens, G.R., O’Neil, J.R., Rea, D.K., Owen, R.M., 1995. Dissociation of oceanic methane hydrate as a cause of the carbon isotope excursion at the end of the Paleocene. Paleoceanog. 10,965-971.

Dickens, G.R., 2003. Rethinking the global carbon cycle with a large, dynamic and microbially mediated gas hydrate capacitor. Earth Planet. Sci. Lett. 213, 169-183.

Ecker, C., Dvorkin, J., Nur, A., 1998. Sediments with gas hydrates: Internal structure from seismic AVO. Geophysics 63, 1659-1669.

Edwards, R.L., Gallup, C.D., Cheng, H., 2003. Uranium-series dating of marine and lacustrine carbonates. Rev. Min. Geochem. 52, 363-405.

Feng, D., Roberts, H.H., Cheng, H., Peckmann, J., Bohrmann, G., Edwards, R.L., Chen, D., 2010. U/Th dating of cold-seep carbonates: an initial comparison. Deep Sea Res. II, 57, 2055-2060.

Fischer, D., Mogollón, J.M., Strasser, M., Pape, T., Bohrmann, G., Fekete, N., Spiess, V., Kasten, S., 2013. Subduction zone earthquake as potential trigger of submarine hydrocarbon seepage. Nat. Geosci. 6, 647-651.

Froelich, P.N., Klinkhammer, G.P., Bender, M.L., Luedtke, N.A., Heath, G.R., Cullen, D., Dauphin, P., Hammond, D., Hartman, B., Maynard, V., 1979. Early oxidation of organic matter in pelagic sediments of the eastern equatorial Atlantic: suboxic diagenesis. Geochim. Cosmochim. Acta 43, 1075-1090.

Greinert, J., Bohrmann, G., Suess, E., 2001. Gas hydrate-associated carbonates and methane venting at Hydrate Ridge: Classification, distribution and origin of carbonate lithologies. In Natural Gas Hydrates: Occurrence, Distribution and Detection (ed. Paull C. K. and Dillon W. P.), Vol. 124, pp. 99-113, American Geophysical Union.

Han, X., Suess, E., Liebetrau, V., Eisenhauer, A., Huang, Y, 2014. Past methane release events and environmental conditions at the upper continental slope of the South China 
Sea: constraints by seep carbonates. Int. J. Earth Sci. DOI 10.1007/s00531-014-10185.

Haq, B.U., 1998. Natural gas hydrates: searching for the long-term climatic and slopeinstability records. In Gas Hydrates: Relevance to World Margin stability and Climate Change (Eds. Henriet J.-P. and Mienert J.). Geol. Soc. Spec. Publ. 137, 303318.

Hesselbo, S.P., Grocke, D.R., Jenkyns, H.C., Bjerrum, C.J., Farrimond, P., Morgans Bell, H.S., Green, O.R., 2000. Massive dissociation of gas hydrate during a Jurassic oceanic anoxic event. Nature 406, 392-395.

Hill, T.M., Kennett, J.P., Spero, H.J., 2004. High-resolution records of methane hydrate dissociation: ODP Site 893, Santa Barbara Basin. Earth Planet. Sci. Lett. 223, 127140.

Hovland, M., Judd, A.G., 1988. Seabed pockmarks and seepages: Impact on Geology, Biology and Marine environment. Graham and Trotman (Eds.), London, Dordrecht, Boston, 293pp.

Hovland, M., Gardner, J.V., Judd, A.G., 2002. The significance of pockmarks to understand fluid flow processes and geohazards. Geofluids 2, 127-136.

Joye, S.M., Boetius, A., Orcutt, B.N., Montoya, J.P., Schulz, H.N., Erickson, M.J., Lugo, S.K., 2004. The anaerobic oxidation of methane and sulphate reduction in sediments from Gulf of Mexico cold seeps. Chem. Geol. 205, 219-238.

Judd, A.G., Hovland, M., Dimitrov, L.I., García Gil, S., Jukes, V., 2002. The geological methane budget at Continental Margins and its influence on climate change. Geofluids 2, 109-126.

Kennett, J.P., Cannariato, K.G., Hendy, I.L., Behl, R.J., 2000. Carbon isotopic evidence for methane hydrate instability during Quaternary interstadials. Science 288, 128-133.

Kutterolf, S., Liebetrau, V., Mörz, T., Freundt, A., Hammerich, T., Garbe-Schönberg, D., 2008. Lifetime and cyclicity of fluid venting at forearc mound structures determined by tephrostratigraphy and radiometric dating of authigenic carbonates. Geology 36, $707-710$. 
Kvenvolden, K.A., Lorenson, T.D., 2001. The Global Occurrence of Natural Gas Hydrates. In Natural Gas Hydrates: Occurrence, Distribution and Detection (ed. Paull C. K. and Dillon W. P.), Vol. 124, pp. 3-18, American Geophysical Union.

Lalou, C., Fontugne, M., Lallemand, S.E., Lauriat-Rage, A., 1992. Calyptogenacemented rocks and concretions from the eastern part of Nankai accretionary prism: Age and geochemistry of uranium. Earth Planet. Sci. Lett. 109, 419-429.

Li, C.-H., Zhao, Q., Xu, H.-J., Feng, K., Liu, X.-W., 2014. Relation between relative permeability and hydrate saturation in Shenhu area, South China Sea. Appl. Geophys. 11, 207-214.

Liebetrau, V., Eisenhauer, A., Linke, P., 2010. Cold seep carbonates and associated coldwater corals at the Hikurangi Margin, New Zealand: new insights into fluid pathways, growth structures and geochronology. Mar. Geol. 272, 307-318.

Liebetrau, V., Augustin, N., Kutterolf, S., Schmidt, M., Eisenhauer, A., Garbe-Schönberg, D., Weinrebe, W., 2014. Cold-seep-driven carbonate deposits at the Central American forearc: contrasting evolution and timing in escarpment and mound settings. Int. J. Earth Sci., DOI 10.1007/s00531-014-1045-2.

Loncke, L., Mascle, J., Fanil Science Party, 2004. Mud volcanoes, gas chimneys pockmarks and ridges in the Nile deep-sea fan (Eastern Mediterranean): geophysical evidences. Mar. Pet. Geol. 21, 669-689.

Ludwig, K.R., 2008. Using Isoplot/Ex, Version 3.70, A geochronological toolkit for Microsoft Excel: Berkeley Geochronology Ctr. Spec. Pub. 4.

Luff, R. Wallmann, K., 2003. Fluid flow, methane fluxes, carbonate precipitation and biogeochemical turnover in gas hydrate-bearing sediments at Hydrate Ridge, Cascadia Margin: numerical modelling and mass balances, Geochim. Cosmochim. Acta 67, 3403-3421.

Luff, R., Greinert, J., Wallmann, K., Klaucke, I., Suess, E., 2005. Simulation of longterm feedbacks from authigenic carbonate crust formation at cold vent sites. Chem. Geol. 216, 157-174. 
Ménot G., Bard, E. 2010. Geochemical evidence for a large methane release during the last deglaciation from Marmara Sea sediments. Geochim. Cosmochim. Acta 74, 1537-1550.

Mienert, J., Vanneste, M., Bünz, S., Handreassen, K., Haflidason, H., Sejrup, H.P., 2005. Ocean warming and gas hydrate stability on the mid-Norwegian margin at the Storegga Slide. Mar. Petrol. Geol. 22, 233-244.

Milkov, A.V., 2004. Global estimates of hydrate-bound gas in marine sediments: how much is really out there? Earth Sci. Rev. 66, 183-197.

Naehr, T.H., Rodriguez, N.M., Bohrmann, G., Paull, C.K., Botz, R., 2000. Methanederived authigenic carbonates associated with gas hydrate decomposition and fluid venting above the Blake Ridge Diapir. Proc. ODP Sci. Res. 164, 286-300.

Niewöhner, C., Hensen, C., Kasten, S., Zabel, M., Schulz, H.D., 1998. Deep sulphate reduction completely mediated by anaerobic methane oxidation in sediments of the upwelling area off Namibia. Geochim. Cosmochim. Acta 62, 455-464.

Nisbet, E., 1990. Climate change and methane. Nature 347, 23.

Panieri, G., James, R.H., Camerlenghi, A., Westbrook, G.K., Consolaro, C., Cacho, I., Cesari, V., Cervera, C.S., 2014. Record of methane emissions from the West Svalbard continental margin during the last 23.500 yrs revealed by $\delta 13 \mathrm{C}$ of benthic foraminifera. Glob. Planet. Change 122, 151-160.

Pastouret, L., Chamley, H., Delibrias, G., Duplessy, J.-C., Thiede, J., 1978. Late Quaternary climatic changes in western tropical Africa deduced from dee-sea sedimentation off the Niger Delta. Oceanol. Acta 1, 217-232.

Pau, M., Hammer, O., 2013. Sediment mapping and long-term monitoring of currents and sediment fluxes in pockmarks in the Oslofjord, Norway. Mar. Geol. 346, 262-273

Pau, M., Hammer, O., Chand, S., 2014. Constraints on the dynamics of pockmarks in the SW Barents Sea: Evidence from gravity coring and high-resolution, shallow seismic profiles. Mar. Geol. 355, 330-345.

Pierre, C., Rouchy, J.M., Gaudichet, A., 2000. Diagenesis in the gas hydrate sediments of the Blake Ridge. Mineralogy and stable isotope compositions of the carbonate and sulphide minerals. Proc. ODP Sci. Res. 164, 139-145. 
Reeburgh, W.S., 1976. Methane consumption in Cariaco Trench waters and sediments. Earth Planet. Sci. Lett. 28, 337-344.

Robinson, L.F., Belshaw, N.S., Henderson, G.M., 2004. U and Th concentrations and isotope ratios in modern carbonates and waters from the Bahamas. Geochim. Cosmochim. Acta 68, 1777-1789.

Rongemaille, E., 2011. Application des terres rares et de la datation U/Th à l'étude des carbonates authigènes de suintements froids: Exemple du delta profond du Niger. PhD Thesis, Institut Universitaire Européen de la Mer, Université de Bretagne Occidentale, Brest, $221 \mathrm{pp}$.

Rongemaille, E., Bayon, G., Pierre, C., Bollinger, C., Chu, N.C., Fouquet, Y., Riboulot, V., Voisset, M., 2011. Rare earth elements in cold seep carbonates from the Niger delta. Chem. Geol. 286, 196-206.

Ruffine, L., Caprais, J.-C., Bayon, G., Riboulot, V., Donval, J.-P., Etoubleau, J., Birot, D., Pignet, P., Rongemaille, E., Chazallon, B., Grimaud, S., Adamy, J., Charlou, J.L., Voisset, M., 2013. Investigation of the geochemical dynamics of a hydratebearing pockmark in the Niger Delta. Mar. Petrol. Geol. 43, 297-309.

Smith, L.M., Sachs, J.P., Jennings, A.E., Anderson, D.M., de Vernal, A., 2001. Light $\delta^{13} \mathrm{C}$ events during deglaciation of the East Greenland continental shelf attributed to methane release from gas hydrates. Geophys. Res. Lett. 28, 2217-2220.

Sowers, T., 2006. Late Quaternary atmospheric $\mathrm{CH}_{4}$ isotope records suggests marine clathrates are stable. Nature $311,838-840$.

Stuiver, M., Reimer, P.J., Reimer, R.W., 2013. CALIB 7.0. [WWW program and documentation].

Suess, E., 2014. Marine cold seeps and their manifestations: geological control, biogeochemical criteria and environmental conditions. Int. J. Earth Sci., DOI $10.1007 / \mathrm{s} 00531-014-1010-0$

Sultan, N., Voisset, M., Marsset, T., Cauquil, E., Colliat, J.-L., Curinier, V., 2007. In situ detection of gas and gas hydrates using 3D seismic data and core penetration testing : Example from the Nigerian continental slope. Mar. Geol. 240, 235-255. 
Sultan, N., Marsset, B., Ker, S., Marsset, T., Voisset, M., Vernant, A.M., Bayon, G., Cauquil, E., Adamy, J., Colliat, J.L., Drapeau, D., 2010. Hydrate dissolution as a potential mechanism for pockmark formation in the Niger delta. J. Geophys. Res 115, B08101.

Sultan, N., Bohrmann, G., Ruffine, L., Pape, T., Riboulot, V., Colliat, J.-L., De Prunelé, A., Dennielou, B., Garziglia, S., Himmler, T., Marsset, T., Peters, C.A., Rabiu, A., Wei, J., 2014. Pockmark formation and evolution in deep water Nigeria: Rapid hydrate growth versus slow hydrate dissolution. J. Geophys. Res.: Sol. Earth 119, 2679-2694.

Teichert, B.M.A., Eisenhauer, A., Bohrmann, G., Haase-Schramm, A., Bock, B., Linke, P., 2003. U/Th systematics and ages of authigenic carbonates from Hydrate Ridge, Cascadia Margin: recorders of fluid flow variations. Geochim. Cosmochim. Acta 67, 3845-3857.

Tong, H., Feng, D., Cheng, H., Yang, S., Wang, H., Min, A.G., Edwards, R.L., Chen, Z., Chen, D., 2013. Authigenic carbonates from seeps on the northern continental slope of the South China Sea: New insights into fluid sources and geochronology. Mar. Petrol. Geol. 43, 260-271.

Tréhu, A.M., et al., 2004. Three-dimensional distribution of gas hydrate beneath southern Hydrate Ridge: constraints from ODP Leg 204. Earth Planet. Sci. Lett. 222, $845-862$.

Wallmann, K., Drews, M., Aloisi, G., Bohrmann, G., 2006. Methane discharge into the Black Sea and the global ocean via fluid flow through submarine mud volcanoes. Earth Planet. Sci. Lett. 248, 544-559.

Wallmann, K., Pinero, E., Burwicz, E., Haeckel, M., Hensen, C., Dale, A., Ruepke, L., 2012. The global inventory of methane hydrate in marine sediments: A theoretical approach. Energies 5, 2449-2498.

Watanabe, Y., Nakai, S., Hiruta, A., Matsumoto, R., Yoshida, K., 2008. U-Th dating of carbonate nodules from methane seeps off Joetsu, Eastern Margin of Japan Sea. Earth Planet. Sci. Lett. 272, 89-96. 
Wei, J.-G. et al. (2015) Gas hydrate distributions in sediments of pockmarks from the Nigerian Margin - Results and interpretation from shallow drilling. Mar. Petrol. Geol. 59, 359-370.

Wirsig, C., Kowsmann, R.O., Miller, D.J., de Oliveira Godoy, J.M., Mangini, A., 2012. U/Th-dating and post-depositional alteration of a cold seep carbonate chimney from the Campos Basin offshore Brazil. Mar. Geol. 329-331, 24-33.

Zabel, M., Schneider, R.R., Wagner, T., Adegbie, A.T., de Vries, U., Kolonic, S., 2001. Late Quaternary climate changes in central Africa as inferred from terrigeneous input to the Niger Fan. Quat. Res. 56, 207-217. 


\section{Figure Captions}

Figure 1: Bathymetric map of the studied area with position of the studied cores. This area corresponds to the collapsed summit of an anticline, which is delimited by two deeprooted normal faults. Note that core N1-KSF-39 is located about $3 \mathrm{~km}$ south-west of core N2-KS-44.

Figure 2: Lithological description of core N2-KS-44 and corresponding pore-water sulphate, calcium and chloride profiles. Analytical uncertainties are within the size of the symbols. Note that original photographs of the studied carbonate concretions can be found in Bayon et al. (2007).

Figure 3: Downcore profiles of Al/Ti ratios for GeoB4901-8 (Zabel et al., 2001), N1KSF-39 and N2-KS-44 (this study), and corresponding age control points. The chronology for core N1-KSF-39 relies on nine 14C-AMS radiocarbon analyses of mixed planktonic foraminifera fractions (Table 1), and tuning of its $\mathrm{Al} / \mathrm{Ti}$ profile to the $\mathrm{Al} / \mathrm{Ti}$ curve of core GeoB4901-8 (dashed lines); a well-dated sediment record also recovered in the Niger Delta deep province (Zabel et al., 2001). The age model for core N2-KS-44 was established by tuning its downcore $\mathrm{Al} / \mathrm{Ti}$ profile to the nearby reference core $\mathrm{N} 1$ KSF-39 (dashed lines).

Figure 4: Backscatter electron (BSE) images of polished sections of carbonate-cemented breccias. (a,b) N2-KS-44_30 cm. (c,d) N2-KS-44_160 cm-1. (e) N2-KS-44_160 cm -2. HMg: microcrystalline high-Mg calcite-cemented mudstones; Fib: Radial fibrous crystals of aragonite; Btr: Botryoidal aragonite; Pyr: Framboidal pyrite; Bio: shell fragments (e.g. bivalves, foraminifera).

Figure 5: Backscatter electron (BSE) image and electron microprobe chemical maps for a carbonate-cemented breccia (N2-KS-44_75cm). HMg: microcrystalline high-Mg 
calcite-cemented mudstones; Fib: Radial fibrous crystals of aragonite; Btr: Botryoidal aragonite; Bio: shell fragments.

Figure 6. Osmond isochron diagram for carbonate concretions and sediments at Site C (core N2-KS-44). Isochron ages are calculated from the slope of the isochrons. The sediment end-member (defined in Fig. 6) is used in all isochrons. The sediment associated with authigenic carbonates at $30 \mathrm{~cm}$ is also used in the isochron. Analytical errors are within the size of symbols.

Figure 7: Relationship between the depth of the sulphate-methane transition zone (SMTZ) and the depth of occurrence of gas hydrate nodules in the study area. The plot was constructed using data for core N2-KS-44 (this study) and previously published data (Rongemaille, 2011; Ruffine et al., 2013; Sultan et al., 2014; de Prunelé et al., 2015).

Figure 8: $\mathrm{Al} / \mathrm{Ti}$, weight proportion of aragonite (Bayon et al., 2007), sediment accumulation rates, and methane-derived carbonate U-Th ages versus stratigraphic age of sediment core N2-KS-44. The grey band represents the aragonite-rich layer between $30 \mathrm{~cm}$ and $180 \mathrm{~cm}$ depth, which corresponds stratigraphically to the time interval $13.0-$ $2.5 \mathrm{ka}$. The dashed black line represents the isochrone connecting carbonate and sediment samples that have the same age. Note that carbonate concretions below $160 \mathrm{~cm}$ depth are characterized by carbonate U-Th ages younger than corresponding stratigraphic ages, while carbonate-cemented breccias from the upper sediment layer display carbonate U-Th ages similar or older than stratigraphic ages.

Figure 9: (a to d) Conceptual model for gas hydrate dynamics and pockmark evolution at the studied site (see text for details). 


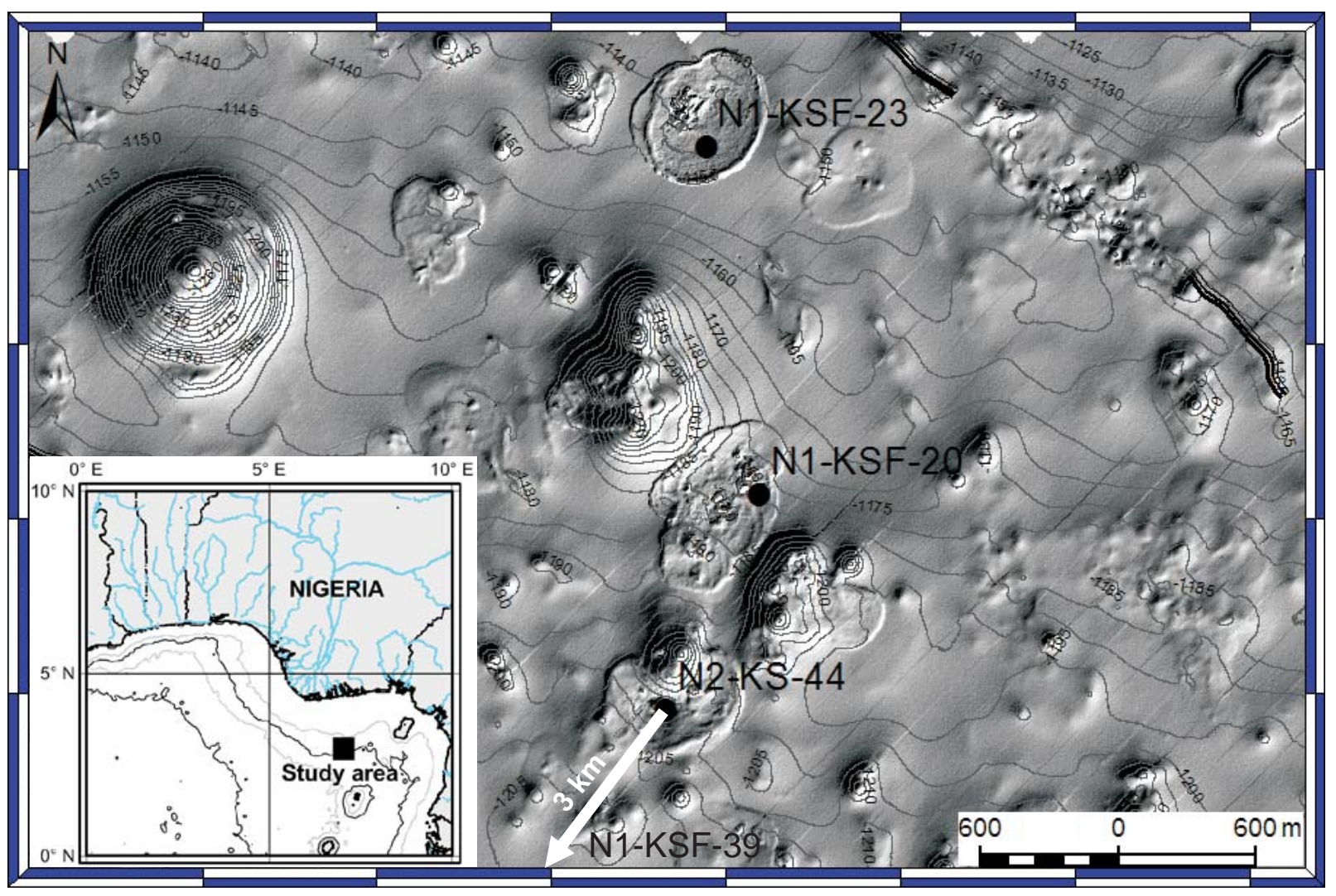

Fig. 1 


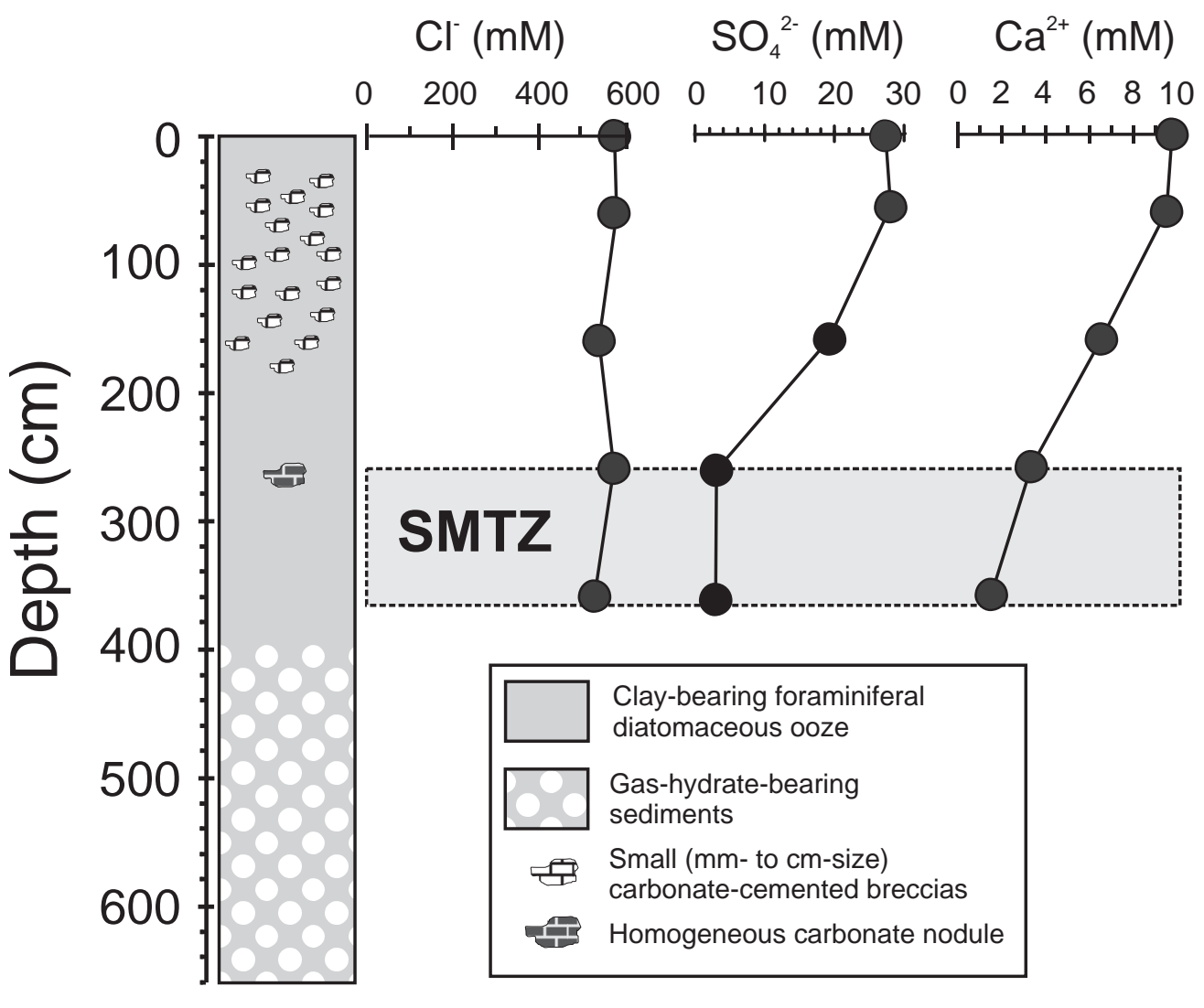

Fig. 2 


\section{$\begin{array}{lll}\mathrm{Al} / \mathrm{Ti} & \mathrm{Al} / \mathrm{Ti} & \mathrm{Al} / \mathrm{Ti}\end{array}$}

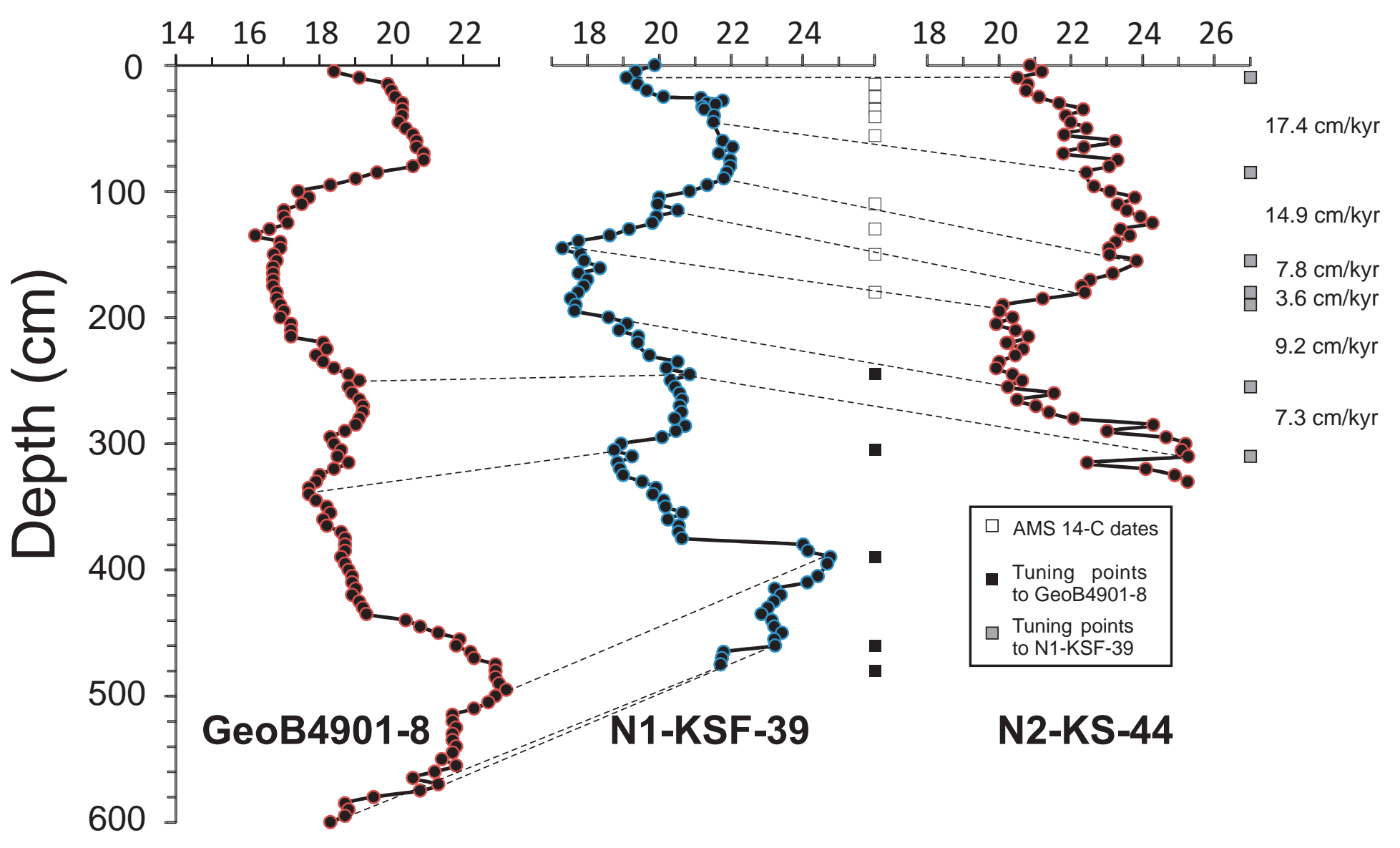

Fig. 3 

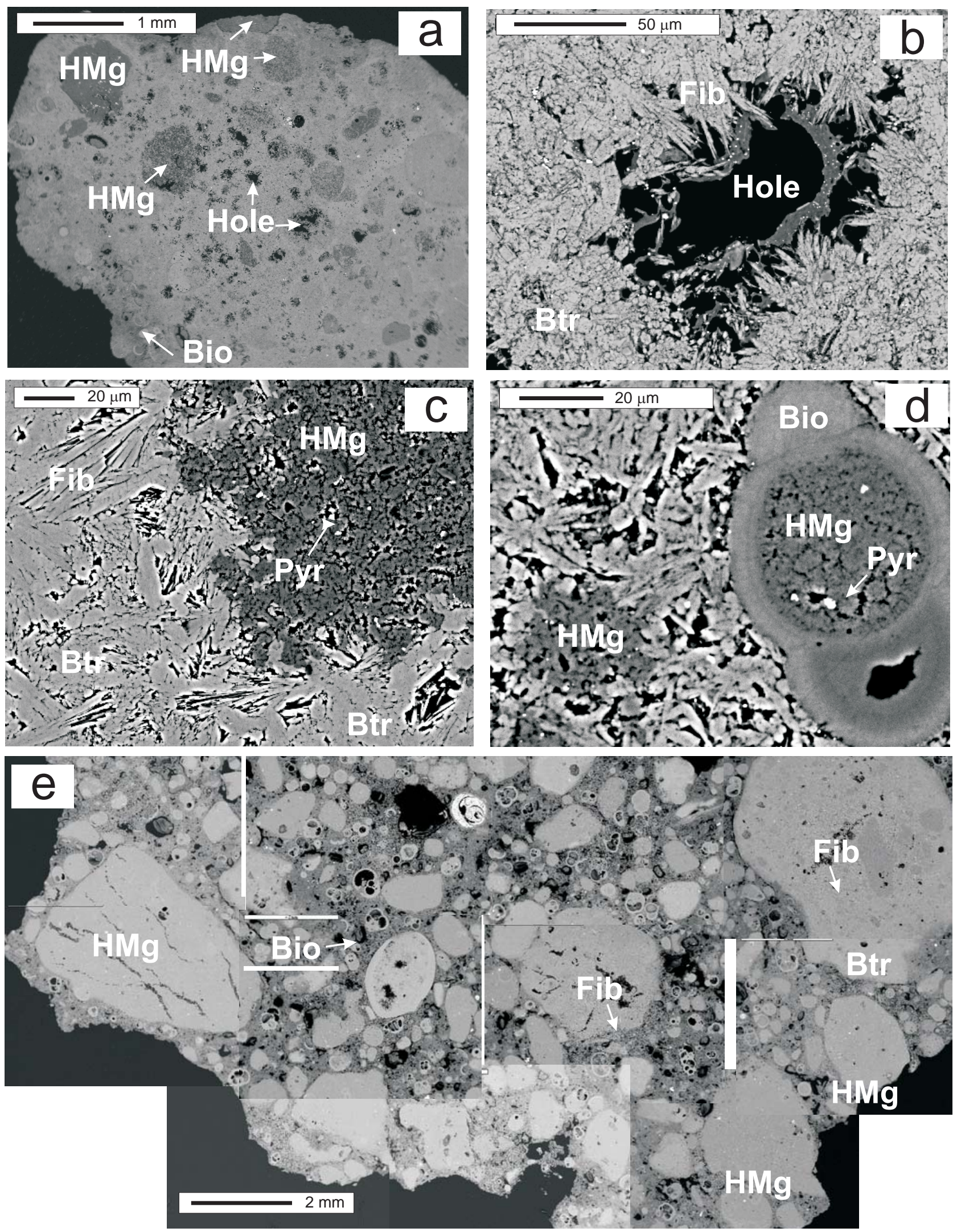

Fig. 4 

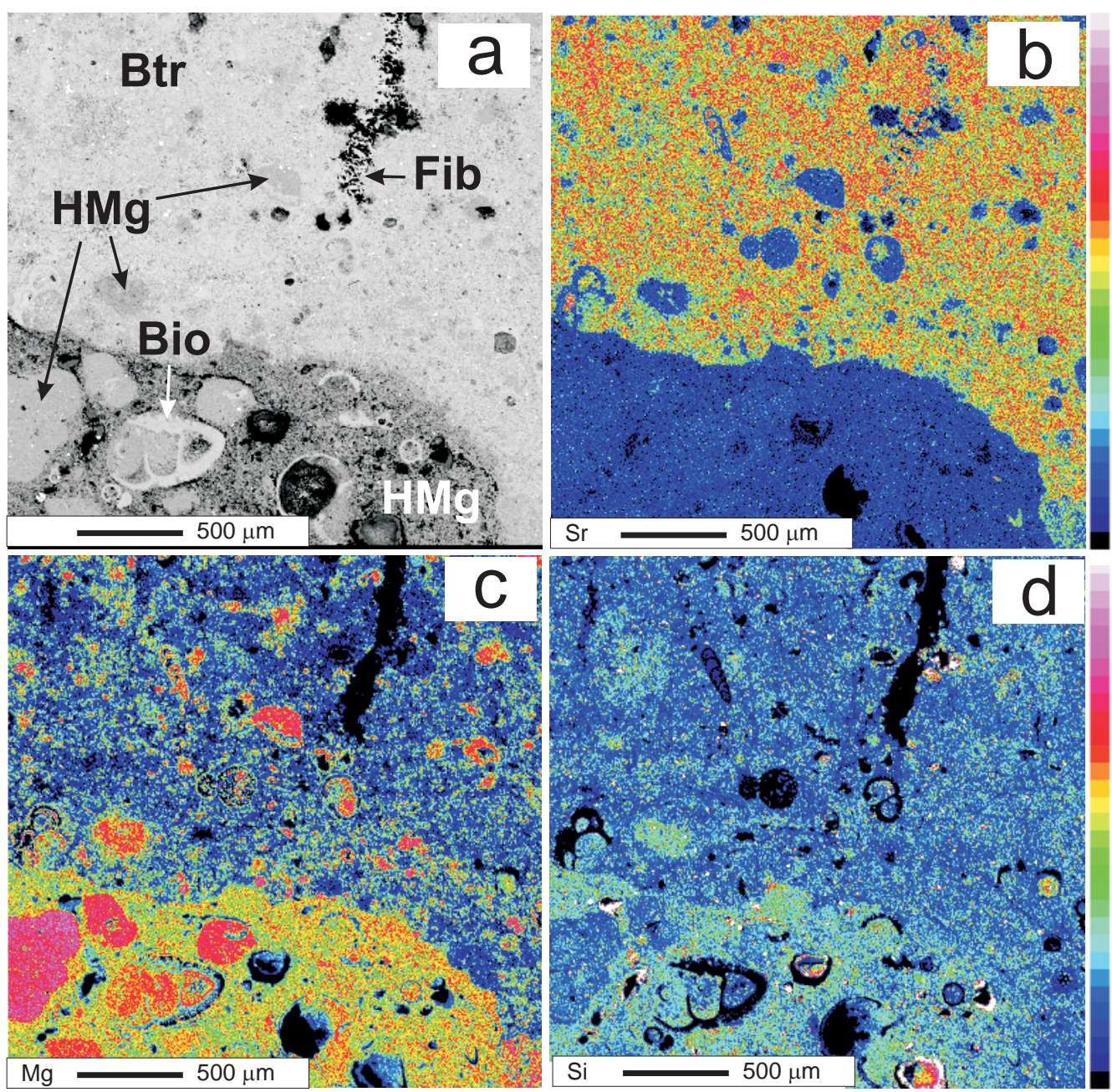

Fig. 5 


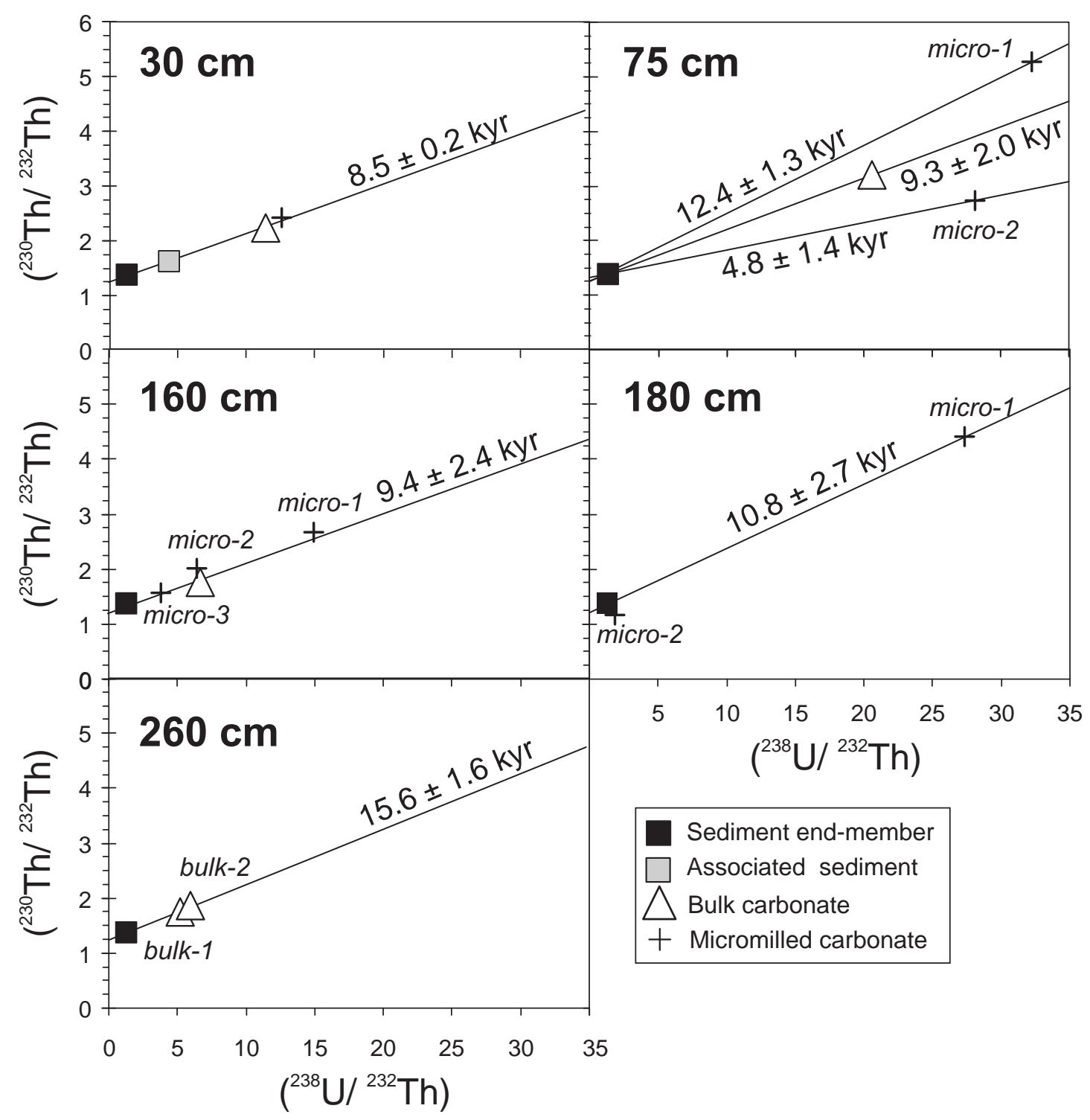

Fig. 6 


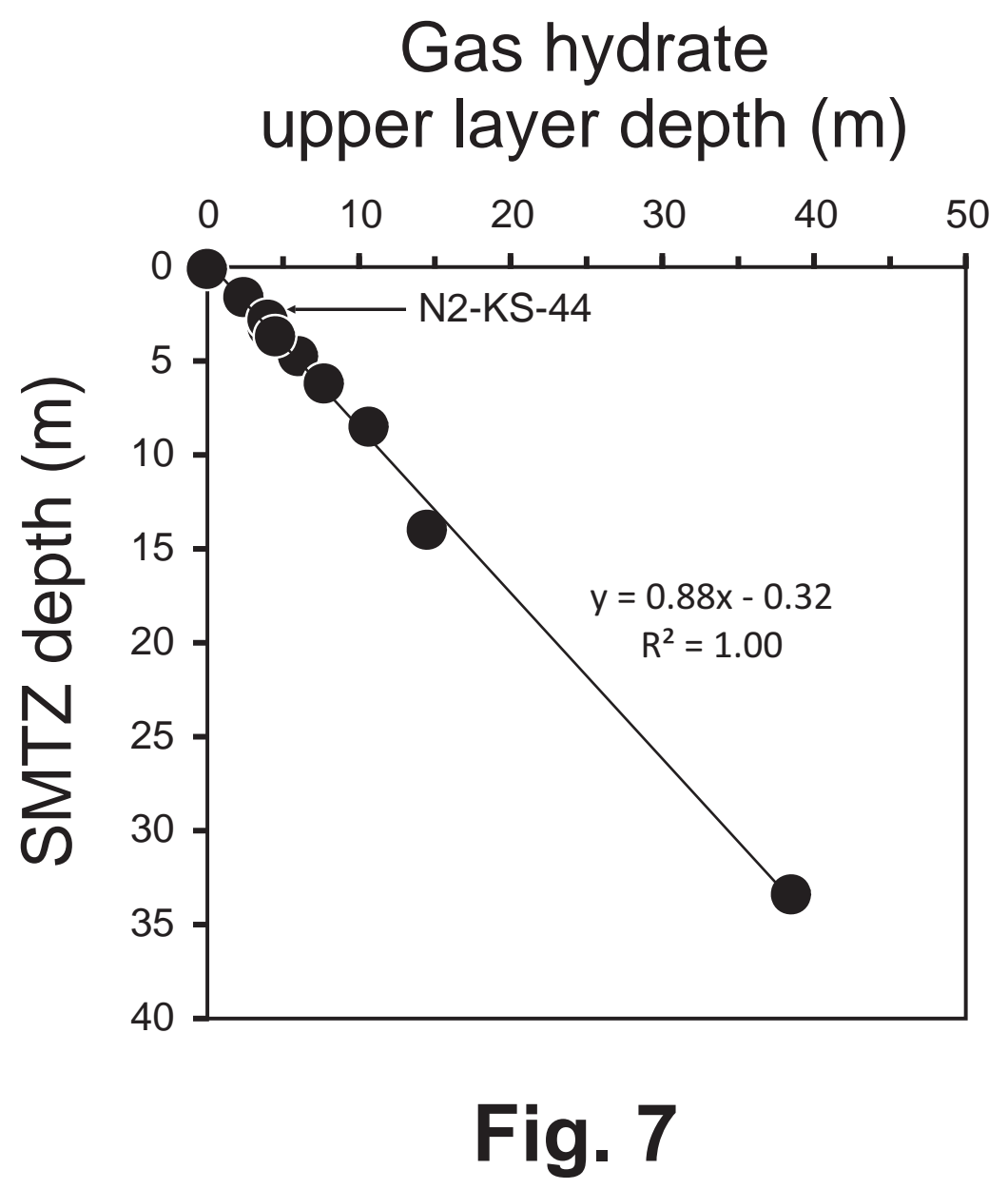




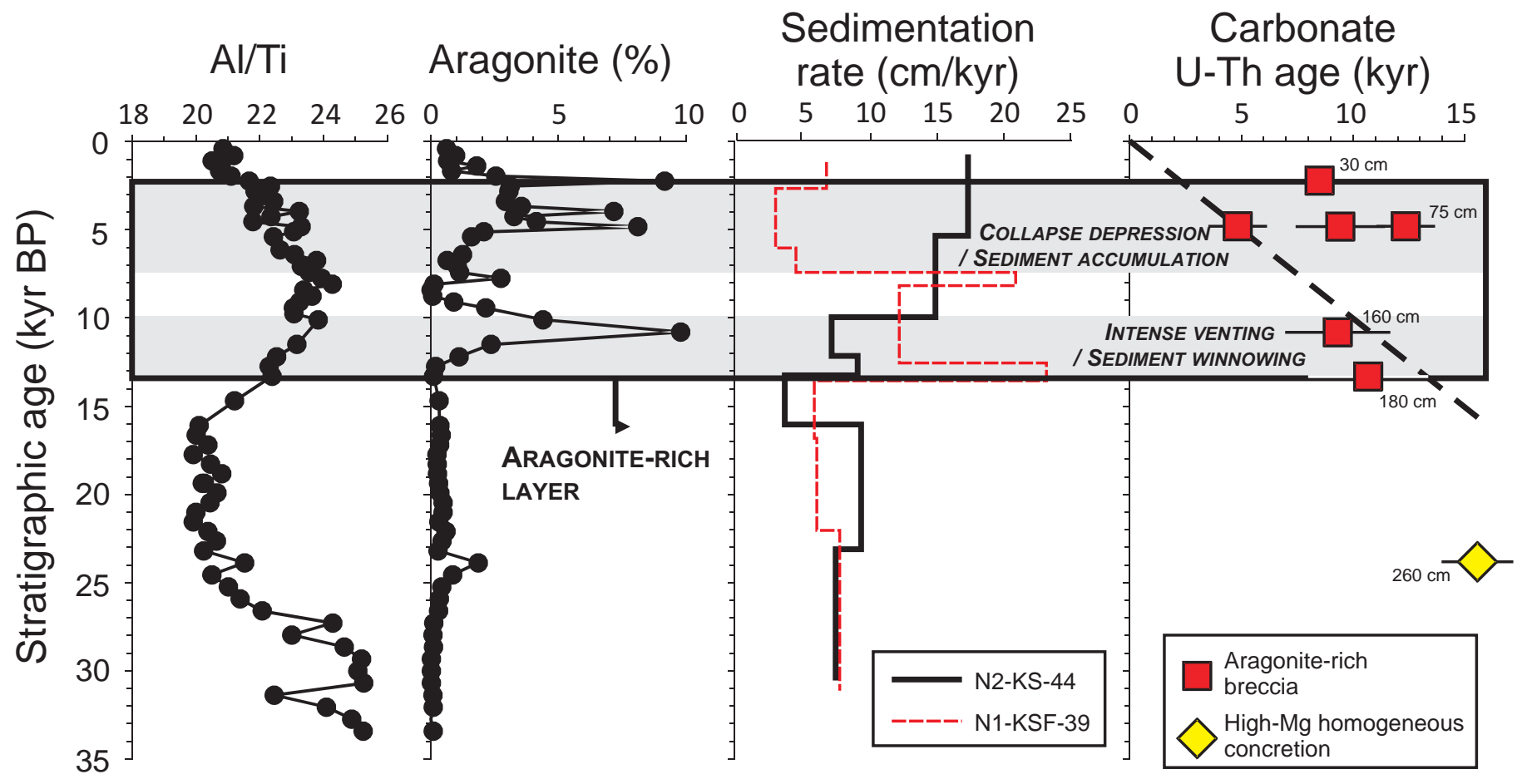

Fig. 8 


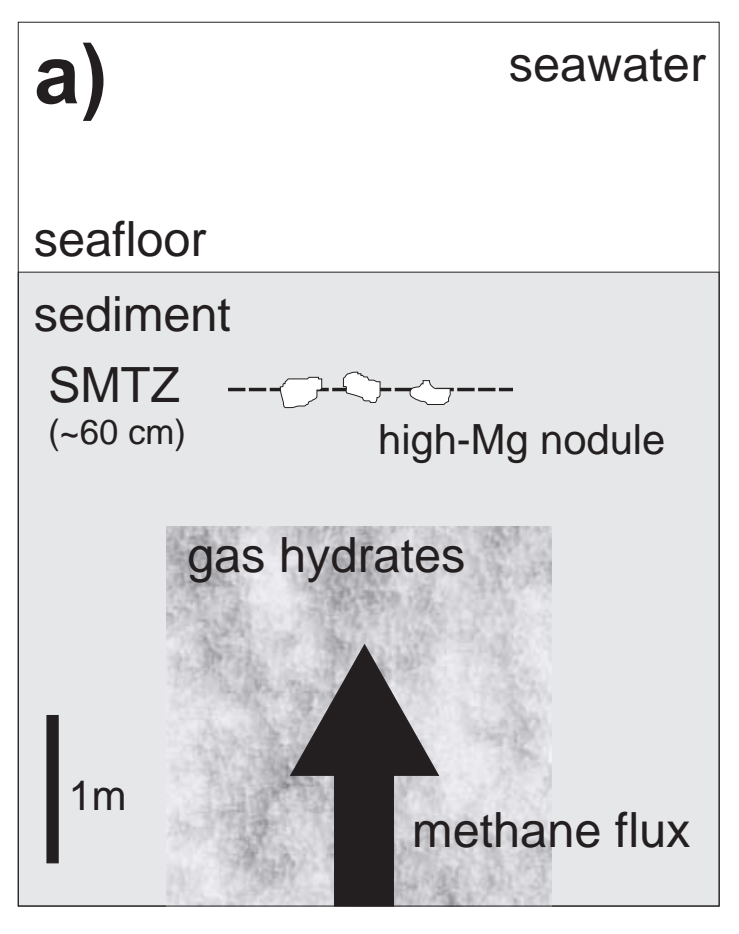

$15 \mathrm{ka}$

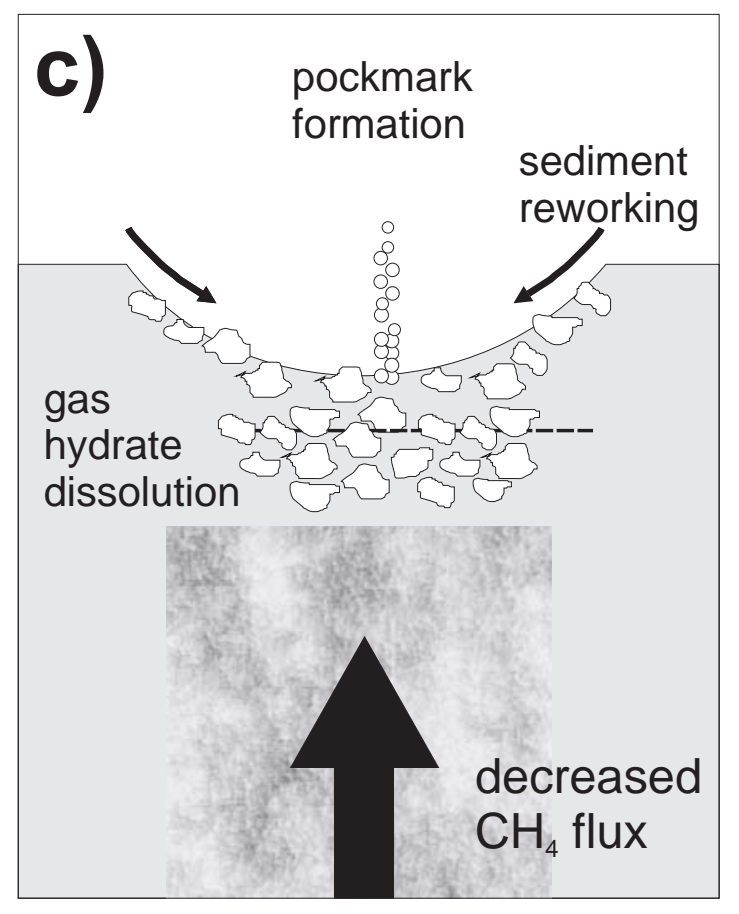

$10-2.5 \mathrm{ka}$

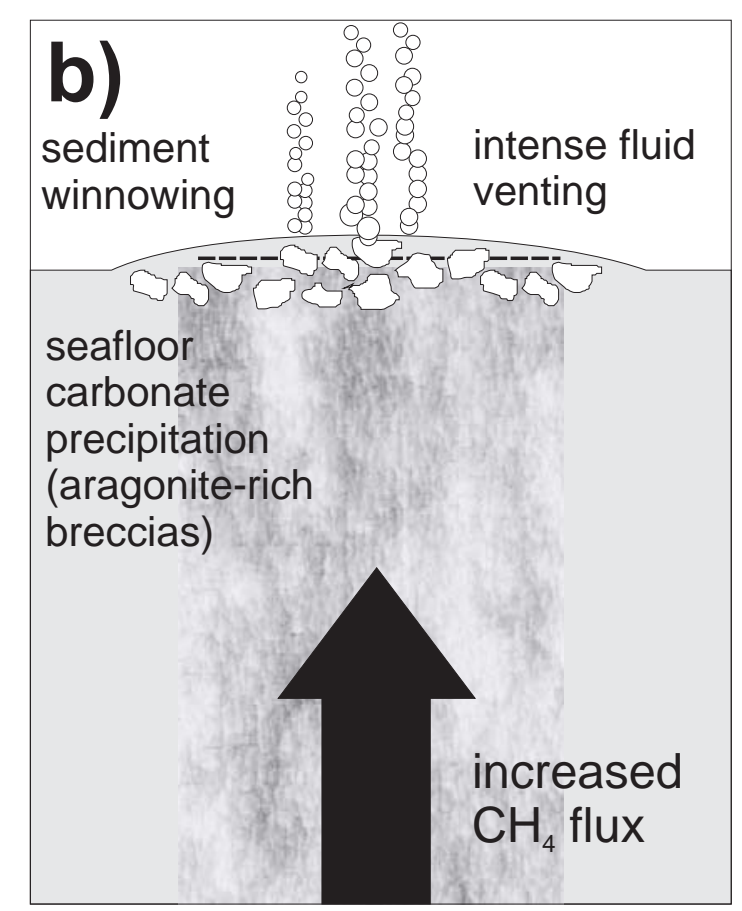

\section{3 - 10 ka}

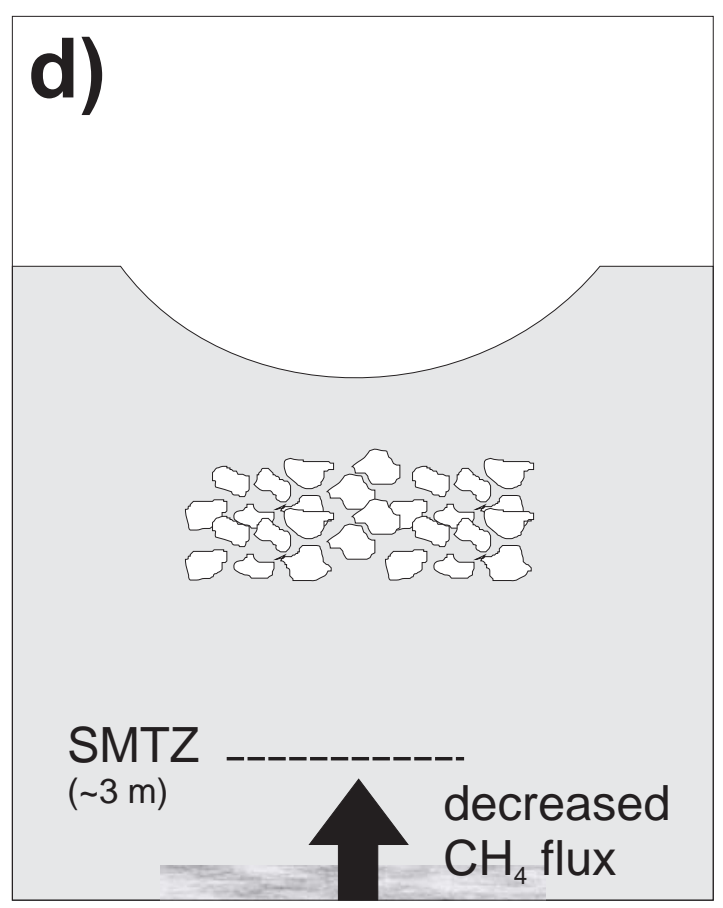

Present-day

Fig. 9 
Table 1. Radiocarbon dates (mixed planktonic foraminifera) and age control points for core N1-KSF-39

\begin{tabular}{|c|c|c|c|c|c|c|}
\hline $\begin{array}{l}\text { Core depth } \\
\qquad(\mathrm{cm})\end{array}$ & Lab code & $\begin{array}{l}{ }^{14} \mathrm{C} \text { age } \\
(\mathrm{yr} \mathrm{BP})\end{array}$ & $\begin{array}{c}\text { Error } \\
\left({ }^{14} \mathrm{C} \text { age } \mathrm{BP}\right)\end{array}$ & $\begin{array}{c}\text { Cal. age range } \\
(1 \sigma) \\
(y r \mathrm{BP})\end{array}$ & $\begin{array}{c}\text { Cal. age } \\
\text { (yr BP) }\end{array}$ & $\begin{array}{c}\text { Sedimentation } \\
\text { rates } \\
(\mathrm{cm} / \mathrm{kyr})\end{array}$ \\
\hline 15 & Poz-30684 & 2,115 & 30 & $1,599-1,800$ & 1,698 & 6.5 \\
\hline 25 & Poz-20113 & 3,375 & 30 & $3,146-3,347$ & 3,243 & 3.0 \\
\hline 35 & Poz-30686 & 6,100 & 40 & $6,418-6,633$ & 6,527 & 4.7 \\
\hline 41 & Poz-20114 & 7,350 & 40 & $7,709-7,917$ & 7,815 & 20.1 \\
\hline 56 & Poz-30687 & 8,100 & 50 & $8,419-8,711$ & 8,560 & 12.2 \\
\hline 110 & Poz-20115 & 11,500 & 50 & $12,802-13,122$ & 12,977 & 20.9 \\
\hline 130 & Poz-30689 & 12,450 & 60 & $13,772-14,095$ & 13,932 & 5.7 \\
\hline 150 & Poz-30690 & 14,740 & 70 & $17,205-17,681$ & 17,468 & 6.1 \\
\hline 180 & Poz-30691 & 18,880 & 100 & $22,022-22,550$ & 22,352 & 7.8 \\
\hline 245 & \multicolumn{4}{|c|}{ Tuning to GeoB4901-8 (Zabel et al., 2001) } & 30,700 & 7.4 \\
\hline 305 & & & & & 42,000 & 5.3 \\
\hline 390 & & & & & 61,600 & 4.3 \\
\hline 460 & & & & & 69,000 & 9.5 \\
\hline 480 & & & & & 73,000 & 5.0 \\
\hline
\end{tabular}


Table 2. Measured U-Th data ( $\pm 2 \mathrm{~s})$ for authigenic carbonates and sediments

\begin{tabular}{|c|c|c|c|c|c|c|c|c|}
\hline Sample & Description & $\begin{array}{c}\text { Weight } \\
\text { (mg) }\end{array}$ & $\begin{array}{l}\text { Dominant } \\
\text { mineral }\end{array}$ & $\begin{array}{c}{ }^{238} U \\
\text { (ppm) }\end{array}$ & $\begin{array}{l}{ }^{230} \mathrm{Th} \\
\text { (ppt) }\end{array}$ & $\left({ }^{230} \mathrm{Th} / /^{232} \mathrm{Th}\right)$ & $\left(\left.{ }^{238} \mathrm{U}\right|^{232} \mathrm{Th}\right)$ & $\begin{array}{c}\delta^{234} U_{(0)} \\
(\%)\end{array}$ \\
\hline \multicolumn{9}{|l|}{ Sediments } \\
\hline $\mathrm{N} 2-\mathrm{KS}-44 \_0 \mathrm{~cm}$ & & 50.1 & & $7.35 \pm 0.01$ & $95.6 \pm 0.6$ & $1.380 \pm 0.005$ & $1.739 \pm 0.008$ & $135 \pm 2$ \\
\hline N2-KS-44_30 cm & & 49.7 & & $16.52 \pm 0.02$ & $100.1 \pm 0.6$ & $1.627 \pm 0.007$ & $4.384 \pm 0.018$ & $141 \pm 2$ \\
\hline N2-KS-44_75 cm & & 50.0 & & $12.34 \pm 0.02$ & $85.2 \pm 0.4$ & $1.300 \pm 0.004$ & $3.082 \pm 0.014$ & $133 \pm 2$ \\
\hline N2-KS-44_330 cm & & 49.8 & & $5.54 \pm 0.01$ & $102.9 \pm 0.6$ & $1.326 \pm 0.008$ & $1.166 \pm 0.004$ & $104 \pm 2$ \\
\hline N1-KSF-20_248 cm & & 51.7 & & $5.67 \pm 0.01$ & $80.9 \pm 0.5$ & $1.444 \pm 0.007$ & $1.654 \pm 0.005$ & $128 \pm 2$ \\
\hline N1-KSF-20_416 cm & & 52.5 & & $5.28 \pm 0.01$ & $104.7 \pm 0.7$ & $1.516 \pm 0.007$ & $1.255 \pm 0.004$ & $114 \pm 2$ \\
\hline N1-KSF-23_0 cm & & 51.2 & & $6.50 \pm 0.01$ & $97.7 \pm 0.5$ & $1.385 \pm 0.006$ & $1.507 \pm 0.005$ & $129 \pm 2$ \\
\hline N1-KSF-23_155 cm & & 52.5 & & $8.88 \pm 0.01$ & $102.3 \pm 0.5$ & $1.262 \pm 0.004$ & $1.788 \pm 0.006$ & $95 \pm 2$ \\
\hline \multicolumn{9}{|c|}{ Carbonate-cemented breccias } \\
\hline \multirow[t]{2}{*}{ N2-KS-44_30 cm } & bulk & 41.1 & Aragonite & $11.47 \pm 0.01$ & $34.5 \pm 0.1$ & $2.20 \pm 0.01$ & $11.94 \pm 0.03$ & $144 \pm 2$ \\
\hline & micromilled-1 & 1.00 & Aragonite & $8.88 \pm 0.18$ & $27.2 \pm 1.0$ & $2.42 \pm 0.08$ & $12.59 \pm 0.37$ & $144 \pm 4$ \\
\hline \multirow[t]{3}{*}{ N2-KS-44_75 cm } & bulk & 109.9 & Aragonite & $22.46 \pm 0.03$ & $54.0 \pm 0.2$ & $3.30 \pm 0.01$ & $22.46 \pm 0.07$ & $149 \pm 2$ \\
\hline & micromilled-1 & 1.09 & Aragonite & $23.52 \pm 0.44$ & $62.4 \pm 1.5$ & $5.28 \pm 0.07$ & $32.26 \pm 0.85$ & $156 \pm 4$ \\
\hline & micromilled-2 & 1.19 & $\mathrm{HMg}$ & $21.56 \pm 0.37$ & $33.8 \pm 0.9$ & $2.74 \pm 0.06$ & $28.16 \pm 0.68$ & $140 \pm 8$ \\
\hline \multirow[t]{4}{*}{ N2-KS-44_160 cm } & bulk & 50.3 & Aragonite / HMg & $7.13 \pm 0.01$ & $29.5 \pm 0.2$ & $1.72 \pm 0.01$ & $6.83 \pm 0.03$ & $133 \pm 2$ \\
\hline & micromilled-1 & 1.15 & Aragonite & $9.04 \pm 0.16$ & $25.9 \pm 0.8$ & $2.67 \pm 0.06$ & $14.90 \pm 0.37$ & $133 \pm 8$ \\
\hline & micromilled-2 & 1.29 & Aragonite & $5.92 \pm 0.10$ & $29.9 \pm 0.8$ & $2.01 \pm 0.04$ & $6.39 \pm 0.15$ & $130 \pm 8$ \\
\hline & micromilled-3 & 1.10 & $\mathrm{HMg}$ & $4.77 \pm 0.09$ & $31.3 \pm 0.7$ & $1.57 \pm 0.02$ & $3.83 \pm 0.10$ & $124 \pm 8$ \\
\hline \multirow[t]{2}{*}{ N2-KS-44_180 cm } & micromilled-1 & 0.91 & Aragonite & $2.28 \pm 0.06$ & $5.2 \pm 0.3$ & $4.41 \pm 0.22$ & $27.35 \pm 0.90$ & $126 \pm 8$ \\
\hline & micromilled-2 & 0.91 & $\mathrm{HMg}$ & $1.83 \pm 0.04$ & $17.7 \pm 0.5$ & $1.16 \pm 0.02$ & $1.87 \pm 0.06$ & $98 \pm 8$ \\
\hline \multicolumn{9}{|c|}{ Homogeneous carbonate nodule } \\
\hline \multirow{2}{*}{$\mathrm{N} 2-\mathrm{KS}-44 \_260 \mathrm{~cm}$} & bulk-1 & 104.2 & $\mathrm{HMg}$ & $4.44 \pm 0.01$ & $24.5 \pm 0.1$ & $1.76 \pm 0.01$ & $5.21 \pm 0.01$ & $127 \pm 2$ \\
\hline & bulk-2 & 116.8 & $\mathrm{HMg}$ & $9.68 \pm 0.01$ & $49.9 \pm 0.2$ & $1.87 \pm 0.01$ & $5.94 \pm 0.01$ & $129 \pm 2$ \\
\hline
\end{tabular}


Table 3. Activity ratios used for age calculation and isochron U-Th ages

\begin{tabular}{|c|c|c|c|c|c|c|c|c|}
\hline Sample & Description & $\begin{array}{c}\text { Dominant } \\
\text { mineral }\end{array}$ & $\left({ }^{232} \mathrm{Th} /{ }^{238} \mathrm{U}\right)$ & $\left({ }^{230} \mathrm{Th} /{ }^{238} \mathrm{U}\right)$ & $\left({ }^{234} U /^{238} U\right)$ & $\begin{array}{l}\text { Two-point } \\
\text { isochron } \\
\text { age (kyr } \pm 2 s)\end{array}$ & $\begin{array}{l}\text { Pseudo- } \\
\text { isochron } \\
\text { age } \\
(\mathrm{kyr} \pm 2 \mathrm{~s})\end{array}$ & $\begin{array}{c}\delta^{234} U_{(T)} \\
(\%)\end{array}$ \\
\hline
\end{tabular}

Sediment end-member $( \pm 1 \mathrm{~s})$

\section{$0.676 \pm 0.1240 .939 \pm 0.196 \quad 1.117 \pm 0.016$}

\section{Carbonate-cemented breccias $( \pm 2 \mathrm{~s})$}

$\begin{array}{cl}\text { N2-KS-44_30 cm } & \begin{array}{l}\text { sediment } \\ \text { bulk } \\ \text { micromilled-1 }\end{array} \\ \text { N2-KS-44_75 cm } & \begin{array}{l}\text { bulk } \\ \text { micromilled-1 }\end{array} \\ \text { ' } & \text { micromilled-2 } \\ \text { sediment }\end{array}$

N2-KS-44_160 cm bulk

micromilled-1

, micromilled-2 micromilled-3

N2-KS-44_180 cm micromilled-1 micromilled-2

Ara
Ara
Ara
Ara
$\mathrm{HMg}$

Ara/HMg
Ara
Ara
$\mathrm{HMg}$
Ara
$\mathrm{HMg}$

Ara

$0.228 \pm 0.001 \quad 0.370 \pm 0.0021 .141 \pm 0.002$ $0.087 \pm 0.000 \quad 0.195 \pm 0.001 \quad 1.144 \pm 0.002$ $0.079 \pm 0.0040 .187 \pm 0.0101 .144 \pm 0.005$ $0.049 \pm 0.000 \quad 0.155 \pm 0.001 \quad 1.149 \pm 0.002$ $0.031 \pm 0.0010 .162 \pm 0.004 \quad 1.156 \pm 0.005$ $0.036 \pm 0.0010 .096 \pm 0.0031 .140 \pm 0.009$ $0.325 \pm 0.0010 .422 \pm 0.0021 .133 \pm 0.002$ $0.150 \pm 0.001 \quad 0.265 \pm 0.001 \quad 1.133 \pm 0.002$ $0.067 \pm 0.0010 .175 \pm 0.0051 .133 \pm 0.009$ $0.156 \pm 0.0030 .309 \pm 0.0091 .130 \pm 0.009$ $0.261 \pm 0.0070 .401 \pm 0.0131 .124 \pm 0.009$ $0.037 \pm 0.001 \quad 0.140 \pm 0.008 \quad 1.126 \pm 0.009$ $0.534 \pm 0.0290 .590 \pm 0.0331 .098 \pm 0.009$

\begin{tabular}{c|rl} 
n.d. & \\
$8.3 \pm 3.8$ & $8.5 \pm 0.2$ & $150 \pm 4$ \\
$8.6 \pm 3.7$ & & \\
$9.3 \pm 2.0$ & $9.3 \pm 2.0$ & $155 \pm 4$ \\
$12.4 \pm 1.3$ & $12.4 \pm 1.3$ & $164 \pm 5$ \\
$4.8 \pm 1.4$ & $4.8 \pm 1.4$ & $143 \pm 10$ \\
n.d. & & \\
$7 \pm 8$ & & \\
$9.0 \pm 2.8$ & & \\
$12 \pm 8$ & & \\
n.d. & & \\
$9.5 \pm 2.4$ & $141 \pm 21$ \\
n.d. & $10.8 \pm 2.7$ & $129 \pm 56$ \\
n.d. & &
\end{tabular}

Homogeneous carbonate nodule $( \pm 2 s)$

N2-KS-44_260 cm bulk-1

$\mathrm{HMg}$

bulk-2

$0.192 \pm 0.000 \quad 0.337 \pm 0.002 \quad 1.127 \pm 0.002$

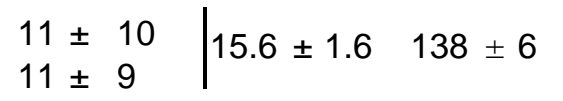



Supplementary Materials
Click here to download Supplementary Materials: Supplementary_material_bayon_2-10-2015.docx

Click here to download Supplementary Materials: Supplementary_material_bayon_2-10-2015.docx

.

$\sqrt{2}$

(1) $\sqrt{20}$ (1) (1) (1) . . . . . . . . . . 